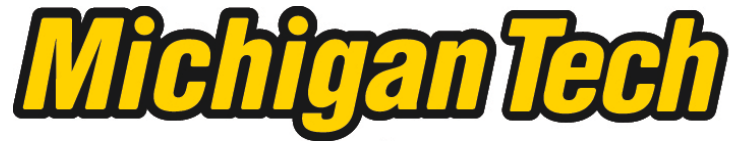 \\ Michigan Technological University Create the Future Digital Commons @ Michigan Tech
}

Dissertations, Master's Theses and Master's Reports - Open

Dissertations, Master's Theses and Master's

Reports

2014

\section{Enzyme Optimization for Lignocellulose Hydrolysis using Mechanistic Modeling}

Adam S. Marlowe

Michigan Technological University

Follow this and additional works at: https://digitalcommons.mtu.edu/etds

Part of the Biochemistry Commons, Chemical Engineering Commons, and the Sustainability

Commons

Copyright 2014 Adam S. Marlowe

\section{Recommended Citation}

Marlowe, Adam S., "Enzyme Optimization for Lignocellulose Hydrolysis using Mechanistic Modeling", Master's Thesis, Michigan Technological University, 2014.

https://doi.org/10.37099/mtu.dc.etds/847

Follow this and additional works at: https://digitalcommons.mtu.edu/etds

Part of the Biochemistry Commons, Chemical Engineering Commons, and the Sustainability Commons 


\title{
ENZYME OPTIMIZATION FOR LIGNOCELLULOSE HYDROLYSIS USING MECHANISTIC MODELING
}

By

Adam S. Marlowe

\begin{abstract}
A THESIS
Submitted in partial fulfillment of the requirements for the degree of MASTER OF SCIENCE

In Chemical Engineering
\end{abstract}

MICHIGAN TECHNOLOGICAL UNIVERSITY

2014

(C) 2014 Adam S. Marlowe 
This thesis has been approved in partial fulfillment of the requirements for the Degree of MASTER OF SCIENCE in Chemical Engineering.

Department of Chemical Engineering

Thesis Advisor: $\quad$ Dr. Wen Zhou

Committee Member: $\quad$ Dr. Robert Handler

Committee Member: $\quad$ Dr. Tony Rogers

Department Chair: $\quad$ Dr. Komar Kawatra 


\section{Table of Contents}

List of Figures................................................................................................................................. iv

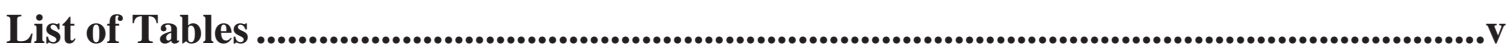

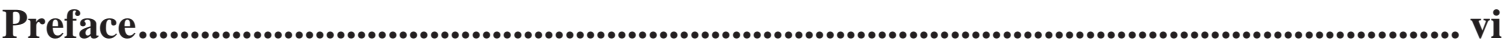

Acknowledgements ..................................................................................................................... vii

List of Abbreviations and Symbols ......................................................................................... viii

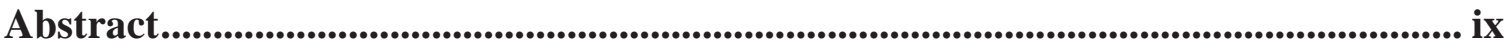

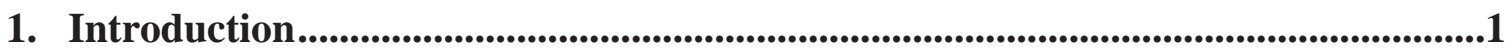

2. Methods..................................................................................................................................

2.1. Morphology of the Substrate .............................................................................

2.2. Enzyme Interactions with Substrate ……………...........................................

2.3. Simulation Parameters ....................................................................................11

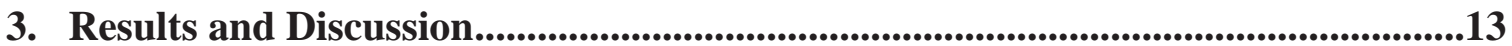

3.1. Optimization of Enzymes for Cellulose Hydrolysis ............................................13

3.2. Optimization of Enzymes for Lignocellulose Hydrolysis ...................................16

3.3. Simulation of Enzyme Addition Time Effects ...................................................21

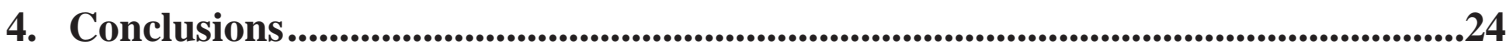

5. Future Work ............................................................................................................................26

6. Bibliography …........................................................................................................................27

Appendix: Enzyme Kinetic Parameters.................................................................................30 


\section{List of Figures}

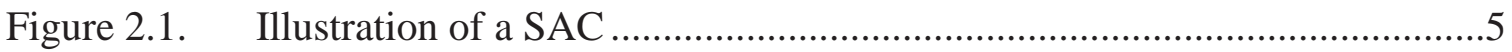

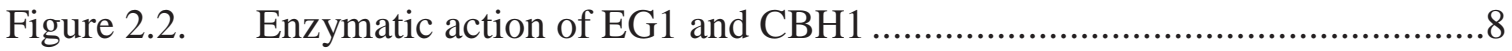

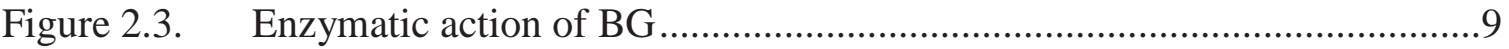

Figure 3.1. Ternary plots of conversion for cellulose hydrolysis..............................13

Figure 3.2. Ternary plots of conversion for lignocellulose hydrolysis ......................17

Figure 3.3. Glucose conversion after addition of BG for cellulose hydrolysis ...........21

Figure 3.4. Glucose conversion after addition of BG for lignocellulose hydrolysis....22

Figure 3.5. Xylose conversion after addition of BX for lignocellulose hydrolysis......22 


\section{List of Tables}

Table 3.1. Predicted optimized enzyme fractions for cellulose hydrolysis ................14

Table 3.2. Predicted optimized enzyme fractions for lignocellulose hydrolysis ........18

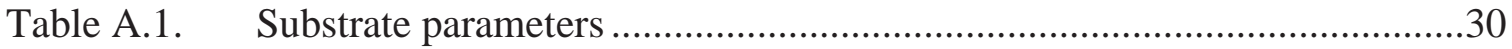

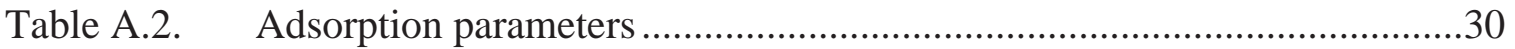

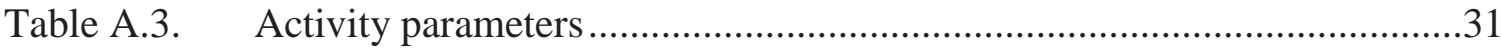

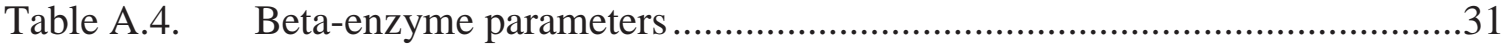

Table A.5. Half-life of enzymes ......................................................................32

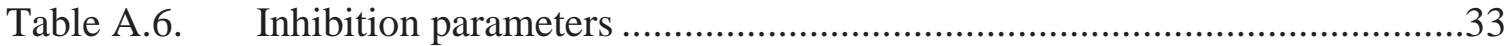




\section{Preface}

The current work is planned for submission in the academic journal Biotechnology and Bioengineering. Contributions were made by Adam S. Marlowe for his work on completing the optimization of enzymes, Yang Zhang for his collaboration while creating the model for optimization, Xi Chen for her work on the enzyme time addition analysis, and Dr. Wen Zhou for his support and expertise on hydrolysis and mechanistic modeling. 


\section{Acknowledgements}

I would like to thank Yang Zhang for his expert advice on the mechanistic model used in this thesis as well as his knowledge and opinion of the mechanisms of enzymatic lignocellulose hydrolysis.

I would also like to thank Dr. Wen Zhou for his support and encouragement throughout my master's education. 


\section{List of Abbreviations and Symbols}

\begin{tabular}{|c|c|}
\hline AFEX & ammonia fiber explosion \\
\hline BG & $\beta$-glucosidase \\
\hline BX & $\beta$-xylosidase \\
\hline CBH1 & cellobiohydrolase I \\
\hline $\mathrm{CBH} 2$ & cellobiohydrolase II \\
\hline DP & degree of polymerization \\
\hline EG1 & endoglucanase I \\
\hline $\mathrm{EX}$ & endo-xylanase \\
\hline $\bar{F}_{A}^{0}$ & initial fraction of accessibility to enzymes \\
\hline$I_{\kappa, \rho}(N)$ & complexation constant of enzyme type $\kappa$ on chain type $\rho$ and DP $N$ \\
\hline$k_{s, \rho}$ & maximum soluble chain length of chain type $\rho$ \\
\hline$L_{\kappa, \mu, \rho}$ & adsorption constant of enzyme type $\kappa$ on chain type $\rho$ to site $\mu$ \\
\hline SAC & smallest accessible compartment \\
\hline$t_{\kappa}$ & time enzyme type $\kappa$ is added to solution \\
\hline$t_{\kappa, 1 / 2}$ & half-life of enzyme type $\kappa$ \\
\hline$u_{\kappa}(t)$ & concentration of active enzyme type $\kappa$ in solution at time $t$ \\
\hline$w_{\kappa}$ & mass fraction of enzyme type $\kappa$ \\
\hline$\gamma_{\kappa, \mu, \rho}$ & specific activity of enzyme type $\kappa$ at site $\mu$ \\
\hline$\kappa$ & index of enzyme type \\
\hline$\lambda_{\sigma}$ & layer number in class- $\sigma \mathrm{SAC}$ \\
\hline$\mu$ & index of site type \\
\hline$\rho$ & index of chain type \\
\hline$\sigma$ & index of SAC class \\
\hline$\Phi_{\sigma, x y l}(\lambda)$ & fraction of hemicellulose in class- $\sigma$, layer $\lambda$ \\
\hline
\end{tabular}




\begin{abstract}
A novel mechanistic model for the saccharification of cellulose and hemicellulose is utilized to predict the products of hydrolysis over a range of enzyme loadings and times. The mechanistic model considers the morphology of the substrate and the kinetics of enzymes to optimize enzyme concentrations for the enzymatic hydrolysis of cellulose and hemicellulose simultaneously. Substrates are modeled based on their fraction of accessible sites, glucan content, xylan content, and degree of polymerizations. This enzyme optimization model takes into account the kinetics of six core enzymes for lignocellulose hydrolysis: endoglucanase I (EG1), cellobiohydrolase I (CBH1), cellobiohydrolase II (CBH2), and endo-xylanase (EX) from Trichoderma reesei; $\beta$ glucosidase (BG), and $\beta$-xylosidase (BX) from Aspergillus niger. The model employs the synergistic action of these enzymes to predict optimum enzyme concentrations for hydrolysis of Avicel and ammonia fiber explosion (AFEX) pretreated corn stover. Glucan, glucan + xylan, glucose and glucose + xylose conversion predictions are given over a range of mass fractions of enzymes, and a range of enzyme loadings. Simulation results are compared with optimizations using statistically designed experiments. BG and BX are modeled in solution at later time points to predict the effect on glucose conversion and xylose conversion.
\end{abstract}




\section{Introduction}

${ }^{1}$ Bioethanol production has received increased attention in recent years due to its potential for reducing greenhouse gas emissions and for decreasing global reliance on petroleum products. The success of bioethanol has been proven by its ability to integrate into the existing infrastructure. Bioethanol is produced largely from first generation biofuels which convert edible biomass into ethanol. Second generation, or advanced, biofuels generated from the biochemical conversion of lignocellulosic biomass have potentially reduced GHG emissions from first generation biofuels (Cherubini et al., 2009). The US seeks to replace $20 \%$ of its current gasoline usage with alternative fuels by 2022, which would increase the US alternative fuel production to 36 billion gallons ( $\mathrm{Gu}$ et al., 2013). Second generation, or advanced, biofuels generated from the biochemical conversion of lignocellulosic biomass have the potential to increase the production of renewable transportation fuels (Singhania et al., 2014), and unlike feedstocks from first generation biofuels, lignocellulose has limited competition with food production (Morales et al., 2014). Enzyme cost is a major barrier facing these biofuels and can represent up to $46 \%$ of total cost of ethanol production (Klein-Marcuschamer et al., 2011). Reducing costs associated with high enzyme loadings by optimizing enzyme titers will help biofuels produced from lignocellulose become an economically viable energy source competitive with petroleum fuels.

Lignocellulose is the main component in plant cell walls and is composed of carbohydrate polymers cellulose (25-55 wt. \%), and hemicellulose (25-40 wt. \%), as well as the aromatic polymer lignin (15-30 wt. \%) (Morales et al., 2014; Zhang et al., 2014; Zhao et al., 2012). Lignocellulose varies in composition depending on the biomass it originates from. The enzymatic hydrolysis of lignocellulose breaks down polymers such as cellulose and hemicellulose into $\mathrm{C}_{5}$ and $\mathrm{C}_{6}$ sugars through the use of hydrolyzing enzymes. These sugars can then be fermented to produce ethanol or other valuable products.

\footnotetext{
${ }^{1}$ To be submitted to Biotechnology and Bioengineering.
} 
Lignocellulose is recalcitrant due to a spatial network that prevents degradation. Factors that are involved in the recalcitrant properties of lignocellulose include surface area accessible to enzymes, cell wall pore size, particle size, and site-specific surface area (Zhao et al., 2012). A number of pretreatment technologies can overcome lignocellulose's recalcitrant properties. Some examples of pretreatment technologies that can be used prior to enzymatic hydrolysis are steam explosion ammonia fiber explosion (AFEX), carbon dioxide explosion, dilute-acid pretreatment, and alkali pretreatments (Kumar et al., 2009). Due to the many types of biomass and pretreatment technologies, the number of substrates that enzymatic hydrolysis may be conducted on vary widely in composition, and structural properties.

As enzymatic hydrolysis continues, hydrolysis rates reduce due to inactivation of enzymes, a decreased site concentration due to a reduction in substrate surface area, and inhibition of enzymes by soluble sugars. Optimizing enzyme concentrations that lead to increased hydrolysis rates is essential for producing the maximum amount of monosaccharides while reducing enzyme loadings. There has been significant effort to develop novel enzyme cocktails that have enhanced synergistic properties for the hydrolysis of cellulose and hemicellulose for specific substrates.

Many groups have attempted the optimization of hydrolyzing enzymes on specific substrates. Berlin et al. 2006 optimized commercial enzyme preparations for the hydrolysis of dilute acid-pretreated corn stover. Gao et al. 2010 used six core enzymes from Trichoderma reesei, Aspergillus niger, and Aspergillus nidulans to optimize enzymes for the hydrolysis of AFEX pretreated corn stover. Banerjee et al. 2010a,b optimized mixtures of ten accessory and six core purified enzymes from Trichoderma reesei and Trichoderma longibrachum on AFEX pretreated corn stover. Billard et al. 2012 optimized EG1, EG2, CBH1, CBH2, xylanase, and the xyloglucanase Cel74a from Trichoderma reesei for the enzymatic hydrolysis of steam-exploded wheat straw. These optimizations account for a single substrate and enzymes from one species. Therefore, 
they cannot account for any substrate or enzymes because they rely on statistically designed experiments that are substrate and enzyme dependent.

Levine et al. 2011 used a mechanistic model to predict the optimized enzyme concentrations for bacterial microcrystalline cellulose. Optimized enzymes included EG2, CBH1, and CBH2. However, in this model they only consider cellulose hydrolysis. Cellulose alone limits the types of substrates that may be represented. Also, they only considered the glucan conversion. Glucose conversion should be considered as glucose is the primary desired product of enzymatic hydrolysis of cellulose.

In this paper, we use a novel mechanistic model reported in Zhang et al. 2014 which is capable of simulating the hydrolysis of cellulose and hemicellulose simultaneously and can predict the yields of unique enzyme titers. It is able to model a wide range of substrates through a variety of substrate parameters which account for the recalcitrant properties of lignocellulose. Because of this, the model is capable of estimating hydrolysis yields from a wide range of feedstocks including microcrystalline celluloses such as bacterial microcrystalline cellulose and Avicel as well as pretreated lignocellulosic biomass.

This enzyme optimization model takes into account the kinetics of the six core enzymes for lignocellulose hydrolysis. The enzymes modeled were endoglucanase I (EG1), cellobiohydrolase I (CBH1), cellobiohydrolase II (CBH2) and endo-xylanase (EX) from Trichoderma reesei; $\beta$-glucosidase (BG), and $\beta$-xylosidase (BX) from Aspergillus niger. These are the core enzymes used in cellulose and hemicellulose hydrolysis (Gao et al., 2011).

Simulation results are presented for the optimization of enzymes on Avicel, a microcrystalline cellulose, as a cellulose substrate and AFEX pretreated corn stover as a lignocellulose substrate. For the first time, the time at which BG and BX are added to solution is modeled. Inactivation of hydrolyzing enzymes is suggested to be occur by thermal and mechanical mechanisms (Ye et al., 2012; Yang et al., 2006). The substrate 
for BG and BX is very dilute at the beginning of hydrolysis. It is shown that by delaying the time at which these enzymes are added to solution it is possible that an increase could be found in the glucose and xylose yield. 


\section{Methods}

\section{Morphology of the Substrate}

Cellulose is composed of linear glucan chains linked by $\beta$-(1,4)-glycosidic bonds.

Cellulose differs between plant species mostly due to the degree of polymerization (DP). Hemicellulose is composed of several saccharide groups, with backbones of mannans, and xylans (Zhang et al., 2014). Lignocellulose can be represented by elementary fibrils and microfibrils. Some experts have suggested that microfibrils of cellulose are composed of 36 linear cellulose chains (Zhao et al., 2012). Dimensions of the crosssectional area of a cellulose microfibril range between 3-5 nm. Microfibrils contain an outside coating of hemicellulose (Yang et al., 2011). Lignin adds mechanical strength to lignocellulose by covalently linking to hemicellulose (Zhao et al., 2012).

In this model, it is assumed that hemicellulose is composed entirely of xylose linked by $\beta-(1,4)$-xylosidic bonds in order to simplify the effects of multiple sugars in hemicellulose. The effects of lignin in this model are neglected.

However in the enzymatic hydrolysis of lignocellulose, lignin hinders the hydrolysis by acting as a physical barrier preventing enzymes from accessing substrate, adsorbing hydrolyzing enzymes, and soluble lignin may deactivate enzymes (Yu et al., 2014; Zhao et al., 2012).

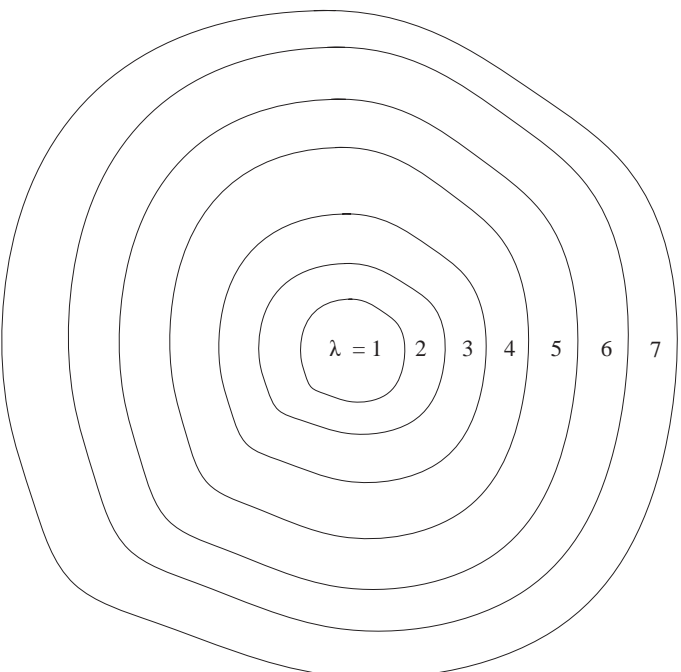

Figure 2.1. Illustration of a SAC. In this case, there are seven layers, and when $\lambda=7$ it represents the outermost layer. As hydrolysis continues, layers are "peeled off', revealing new layers underneath and exposing them for hydrolysis.

Microfibrils are mapped to smallest accessible compartments (SAC) and SAC layers. An SAC is the minimal volume that is delimited by external surfaces and by internal surfaces exposed to enzyme-accessible 
internal hydrated voids of the solid substrate (Zhou et al., 2009a). The hydrolytic time evolution leads to surface ablation of the SAC. This leads to shrinkage of the size of the SAC, which models the solubilization of the substrate as enzymatic hydrolysis continues.

The complexity of substrate particles is represented by an index of SAC classes, represented by $\sigma$. This index represents SAC classes which differ by number of SAC layers, or in composition of cellulose and hemicellulose. The size of an SAC class is modelled by its number of layers. The index of layers is represented by $\lambda_{\sigma}$ for SAC class $\sigma$. The particle layer number, $\lambda_{\sigma}$, increases as the layer becomes closer to the outermost layer. Figure 2.1 shows an example of what a SAC may represent. Since there are a number of types of chains in the model, the index of chain type is represented by $\rho$. This distinguishes between glucan and xylan chains.

Each hydrolysis simulation that contains hemicellulose has a fraction of xylan for each SAC layer which is a function of the layer number, represented by $\Phi_{\sigma, x y l}\left(\lambda_{\sigma}\right)$. This represents the fraction of the SAC layer that is composed of xylan chains. At the beginning of hydrolysis when $\lambda_{\sigma}$ is the largest for a particular SAC, in other words the outermost layer, $\Phi_{\sigma, x y l}^{0}\left(\lambda_{\sigma, \max }\right)$, represents the initial fraction of exposed xylan in a $\sigma$ SAC class. As an effort to make SAC classes containing hemicellulose ablate similar to how lignocellulose solubilizes, lower number layers always have fractions of xylan less than higher number layers. This is based on the structure of a microfibril of lignocellulose because hemicellulose coats the outside of cellulose microfibril. Inner layers will contain a higher concentration of glucan chains, which represents the structure of a cellulose microfibril.

Each SAC has an initial fraction of accessible sites, $\bar{F}_{A, \sigma}^{0}$, which represents the ratio of sites exposed on the surface of a $\sigma$ SAC class by the number of total sites in a $\sigma$ SAC class. Also, a fraction of glucan and xylan are modeled in separate SAC classes in order to approximate the separation of a portion of cellulose and hemicellulose after pretreatment. 
The model creates a Gaussian distribution of SAC concentrations based on a SAC class's number of layers, and the initial fraction of exposed xylan in all SAC classes. The Gaussian distribution will make the concentrations of SAC classes to match the total desired initial fraction of accessible sites, $\bar{F}_{A}^{0}$. Fore more information on SAC classes please see Zhang et al., 2014 and Zhou et al., 2009a.

There are a number of sites present in the model, which are represented by index $\mu$. Based on the function of enzymes, enzymes classes may adsorb and catalyze reactions at particular site types. N, X, and Y sites represent $\beta$-(1,4)-glucosidic or $\beta$-(1,4)-xylosidic bonds. $\mathrm{X}$ sites represent sites for adsorption by $\mathrm{CBH} 2$ on the non-reducing end while $\mathrm{Y}$ sites represent sites for adsorption by $\mathrm{CBH} 1$ on the reducing end. $\mathrm{N}$ sites represent any exposed bond along a cellulose or xylose chain (Zhou et al., 2009a).The concentration of site type $\mu$ of chain type $\rho$ at layer $\lambda$ of $\sigma$ SAC class is represented by $x_{\mu, \rho, \sigma}\left(\lambda_{\sigma}\right)$ which is a function of the layer number. For more information on sites modeled please see Zhang et al., 2014 and Zhou et al., 2009a. At the start of hydrolysis, sites exposed to the surface of the SAC class have the maximum layer for that SAC class, or $\lambda_{\sigma, \max }$. At the start of hydrolysis, the concentration of all sites exposed for hydrolysis in a SAC class $\sigma$ can be expressed as

$$
x_{M, \sigma}=\sum_{\mu=1}^{P} \sum_{\rho}^{Q} x_{\mu, \rho, \sigma}\left(\lambda_{\sigma, \max }\right)
$$

where $\mathrm{P}$ is the number of types of sites, $\mathrm{Q}$ is the number of chain types, and $\mathrm{M}$ indicates the SAC surface.

At the beginning of hydrolysis, it is assumed that the length of all chains of type $\rho$ is equal to the initial DP of chain type $\rho$. As chains are cut, the length of the chain is modified depending on what site is cut, and where along the cellulose chain the site that is cut is located. 


\section{Enzyme Interactions with Substrate}

Enzyme types are represented by index $\kappa$. Enzymes are modeled based on a specific adsorption constant $\left(L_{\kappa, \mu, \rho}\right)$ in $\mathrm{L} / \mathrm{mmol}$ to chain types $\rho$ and sites $\mu$. Adsorption of enzymes onto the surface of an SAC is treated at pseudo-equilibrium based on the concentration of free enzyme types, free sites exposed, and enzyme-substrate complexes. The specific activity of each enzyme-substrate complex is modeled at a constant rate of hydrolysis (Zhou et al. 2009a). Adsorbed enzymes to chain type $\rho$ and site $\mu$ have an activity constant $\left(\gamma_{\kappa, \mu, \rho}\right)$ in mmol bond cleaved (mmol enzyme $)^{-1} \min ^{-1}$ based on the enzyme type, chain type, and site adsorbed. EG1, CBH1, CBH2, and EX can adsorb onto the surface of the substrate to form an enzyme-substrate complex.
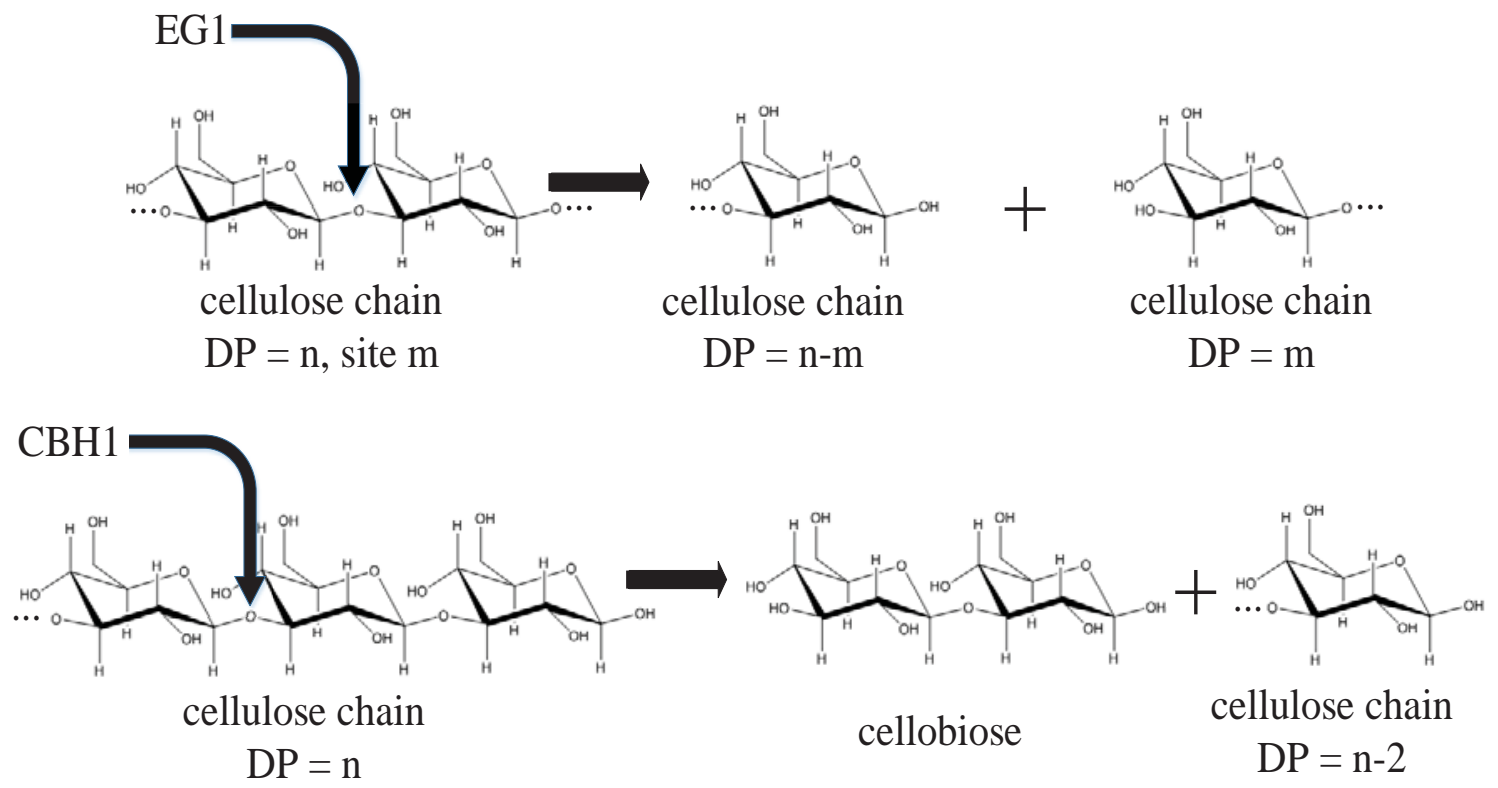

Figure 2.2. Enzymatic action of EG1 and CBH1. An equilibrium exists between EG1, $\mathrm{CBH} 1$ and the sites that they may adsorb to. The concentration that is adsorbed to form an enzyme-substrate complex has a catalytic rate at which its product is produced. EG1 acts on any exposed site to produce separate insoluble chain ends or soluble oligosaccharides while $\mathrm{CBH} 1$ acts on the reducing end of the cellulose chain to release cellobiose. EX works similarly to EG1 except on xylan chains while $\mathrm{CBH} 2$ works similarly to $\mathrm{CBH} 1$ except on the non-reducing end of a cellulose chain. 
BG and BX do not adsorb to a substrate, but act on soluble oligomers. They have an complexation constant, $I_{\kappa, \rho}(N)$ in L/mmol based on the enzyme type, chain type and DP of the soluble oligomers and an activity constant, $\gamma_{\kappa, \rho}(N)$ in mmol bond cleaved (mmol enzyme $)^{-1} \mathrm{~min}^{-1}$ based on the enzyme type, chain type and DP of the soluble oligomers. Their activity is dependent upon the activity constant, and the concentration of soluble oligomers of chain type $\rho$ and DP $N$ in solution.

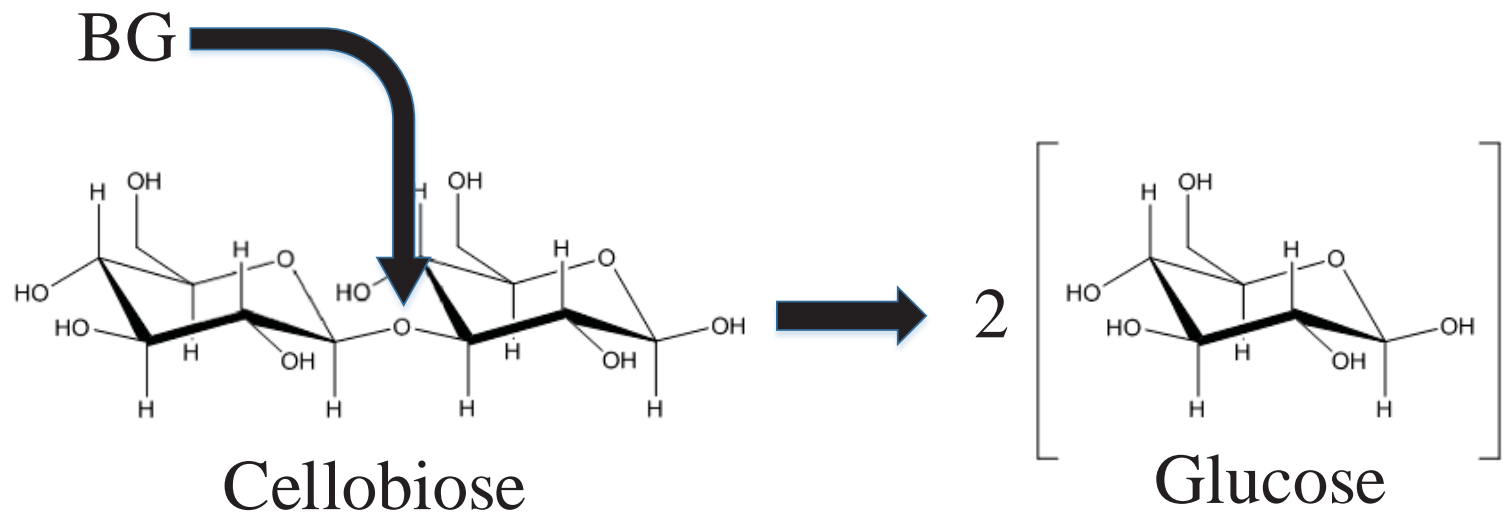

Figure 2.3. Enzymatic action of BG. BG acts on soluble glucan oligosaccharides to form glucose. Since there is no adsorption to the substrate surface, only an activity rate constant and a complexation equilibrium constant to determine the hydrolysis rate of BG. BX works similarly on soluble xylan oligosaccharides to form xylose.

Enzyme inhibition occurs when soluble oligomers complex with enzymes. Soluble oligomers of xylan are modeled with much stronger inhibition for EG1, CBH1, and CBH2 than soluble oligomers of glucan. All enzyme types $\kappa$ have inhibition constants, $I_{\kappa, \rho}(N)$, to soluble oligomers of DP $N$ and chain type $\rho$.

Enzyme inactivation occurs as hydrolysis time increases. Hydrolyzing enzymes are known to undergo thermal and mechanistic inactivation. Enzyme activity is time dependent and decreases according to a half-life model. $\mathrm{u}_{\mathrm{\kappa}}(t)$ is the concentration of active enzyme $\kappa$ in solution, $\mathrm{u}_{\kappa, 0}$ is the concentration of enzyme at the addition of enzyme into solution, $t_{\kappa}$ is the time at which enzyme $\kappa$ is added to solution, and $t_{\kappa, 1 / 2}$ is 
the half-life of enzyme $\kappa$, and $t$ is time. Then the concentration of active enzyme $\kappa$ at time $t$ is:

$$
\begin{gathered}
t<t_{\kappa}, \mathrm{u}_{\kappa}(t)=0 \\
t \geq t_{\kappa}, \mathrm{u}_{\kappa}(t)=\mathrm{u}_{\kappa, 0}\left(\frac{1}{2}\right)^{\frac{t-t_{\kappa}}{t} \kappa_{\frac{1}{2}}}
\end{gathered}
$$

Because of the inactivation of enzymes, model predictions were made to give the monosaccharide production dependent on the time at which BG and BX were added to solution.

As long as another enzyme has the same major function as EG1, CBH1, CBH2 and EX from Trichoderma reesei as well as BG, and BX, from Aspergillus niger the model can easily account for the hydrolysis effects of these enzymes as long as molecular weight, specific activity to site constants, adsorption constants, inhibition constants and half-lives are used. Enzymes are classified into types, and as long as enzymes have the same main function as previously assigned types, other enzymes can be modeled.

As hydrolysis occurs, the surface layer ablation of an SAC represents glucan and xylan oligomers hydrolyzed into solution. This exposes SAC layers underneath to enzyme action. Due to a shrinkage in SAC surface area, this leads to a decrease in accessible sites. This will cause a reduction in the enzyme-substrate complex, resulting in a decrease in the hydrolytic rate. 


\section{Simulation Parameters}

Avicel, a microcrystalline cellulose, and AFEX pretreated corn stover were modeled. Avicel is assumed to be composed of $100 \%$ glucan. Optimization of enzymes EG1, CBH1, CBH2, and BG were determined for glucan conversion and glucose conversion. No EX or BX were used for the optimization of enzymes on Avicel because there would be no sites for these enzymes to act. For cellulose and hemicellulose hydrolysis, the substrate was modeled as AFEX pretreated corn stover. In this model, it is assumed that AFEX pretreated corn stover is composed of 39.6\% glucan and 24.5\% xylan (Qing and Wyman 2011). Optimization of enzymes EG1, CBH1, CBH2, EX, BG, and BX were found for glucan + xylan conversion and glucose + xylose conversion .

The model was simulated for 24, 48, and 72 hours. Enzyme loadings modeled were 7.5, 15, and 30 mg enzyme/g glucan for Avicel and AFEX pretreated corn stover. The model was iterated with changes to the mass fraction of enzymes, $w_{\kappa}$, such that $\sum_{\kappa} w_{\kappa}=1$. Chain type $\rho$ conversion is the sum of the concentration of all $\rho$ monomer units present in solution divided by the total concentration of $\rho$ monomer units. Chain type $\rho$ monomer conversion is the concentration of soluble monosaccharides of chain type $\rho$ divided by the total concentration of $\rho$ monomer units.

$$
\begin{gathered}
\rho \text { conversion }(\%)=\frac{100}{x_{V, \rho, 0}} \cdot \sum_{N} n \cdot x_{S, \rho}(N) \\
\rho \text { monomer conversion }(\%)=\frac{100}{x_{V, 0}} \cdot x_{S, \rho}(N)
\end{gathered}
$$

where $x_{S, \rho}(N)$ is the concentration of soluble oligosaccharide of chain type $\rho$, with a DP

of $N$ and $x_{V, \rho, 0}$ is the total concentration of $\rho$ monomer units in the substrate at the start of hydrolysis.

After the optimal enzyme concentration for glucose conversion and xylose conversion were found for all simulations, BG and BX were modeled to be added at 0,24 , and 48 hours to see the effect of adding BG and BX after all other enzymes. The idea is that 
substrate for $\mathrm{BG}$ and $\mathrm{BX}$ is very low at the beginning of hydrolysis, and by delaying the time entry of BG and BX, rates of hydrolysis for these enzymes will increase which will increase the glucose conversion and xylose conversion. 


\section{Results and Discussion}

\section{Optimization of Enzymes for Cellulose Hydrolysis}

The model was successful in finding an optimization point for glucan conversion and glucose conversion for all simulations on an Avicel substrate. Figure 3.1.A-F shows ternary plots of glucan conversion and glucose conversion for EG1, CBH1, CBH2, and BG at 72 hours with enzyme loadings of 7.5, 15, and $30 \mathrm{mg}$ enzyme/g substrate. Table 3.1.A-F shows the predicted enzyme optimization titers for cellulose hydrolysis simulations at 24, 48, and 72 hours with enzyme loadings of 7.5, 15, and $30 \mathrm{mg}$ enzyme/g substrate.

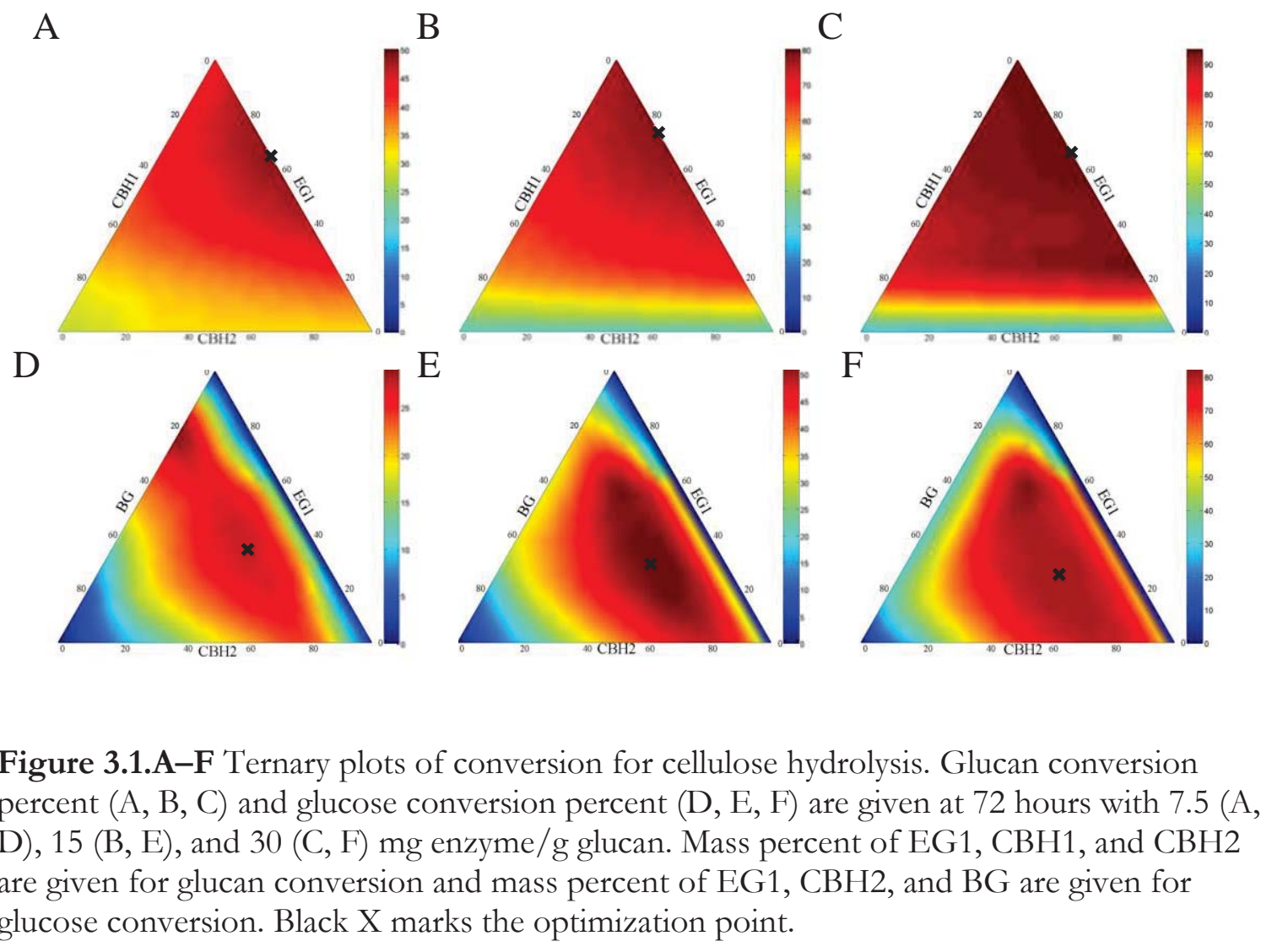


Table 3.1.A-F. Predicted optimized enzyme fractions for cellulose hydrolysis. Optimized enzyme mass fractions are presented for the hydrolysis of Avicel substrate with predicted optimized glucan conversion (\%), and predicted optimized glucose conversion (\%) for a given time of hydrolysis (24, 48, 72 hours). A \& D - $7.5 \mathrm{mg}$ enzyme/g glucan, B \& E - $15 \mathrm{mg}$ enzyme/g glucan, C \& F - $30 \mathrm{mg}$ enzyme/g glucan.

A

\begin{tabular}{|l|l|l|l|l|l|}
\hline Time & EG1 & CBH1 & CBH2 & BG & $\begin{array}{l}\text { Glucan } \\
\text { Conversion }\end{array}$ \\
\hline 24 & 0.58 & 0.00 & 0.42 & 0.00 & 24.7 \\
\hline 48 & 0.62 & 0.00 & 0.38 & 0.00 & 39.3 \\
\hline 72 & 0.64 & 0.00 & 0.36 & 0.00 & 48.5 \\
\hline
\end{tabular}

B

\begin{tabular}{|l|l|l|l|l|l|}
\hline Time & EG1 & CBH1 & CBH2 & BG & $\begin{array}{l}\text { Glucan } \\
\text { Conversion }\end{array}$ \\
\hline 24 & 0.64 & 0.00 & 0.36 & 0.00 & 43.2 \\
\hline 48 & 0.70 & 0.00 & 0.30 & 0.00 & 52.3 \\
\hline 72 & 0.74 & 0.00 & 0.26 & 0.00 & 70.7 \\
\hline
\end{tabular}

C

\begin{tabular}{|l|l|l|l|l|l|}
\hline Time & EG1 & CBH1 & CBH2 & BG & $\begin{array}{l}\text { Glucan } \\
\text { Conversion }\end{array}$ \\
\hline 24 & 0.62 & 0.00 & 0.38 & 0.00 & 62.8 \\
\hline 48 & 0.64 & 0.00 & 0.32 & 0.02 & 85.2 \\
\hline 72 & 0.66 & 0.00 & 0.32 & 0.02 & 94.2 \\
\hline
\end{tabular}

D

\begin{tabular}{|l|l|l|l|l|l|}
\hline Time & EG1 & CBH1 & CBH2 & BG & $\begin{array}{l}\text { Glucose } \\
\text { Conversion }\end{array}$ \\
\hline 24 & 0.40 & 0.00 & 0.40 & 0.20 & 15.9 \\
\hline 48 & 0.40 & 0.00 & 0.38 & 0.22 & 24.1 \\
\hline 72 & 0.38 & 0.00 & 0.38 & 0.24 & 27.5 \\
\hline
\end{tabular}

$\mathbf{E}$

\begin{tabular}{|l|l|l|l|l|l|}
\hline Time & EG1 & CBH1 & CBH2 & BG & $\begin{array}{l}\text { Glucose } \\
\text { Conversion }\end{array}$ \\
\hline 24 & 0.46 & 0.00 & 0.36 & 0.18 & 31.7 \\
\hline 48 & 0.48 & 0.00 & 0.32 & 0.2 & 46.6 \\
\hline 72 & 0.46 & 0.00 & 0.32 & 0.22 & 52.6 \\
\hline
\end{tabular}

F
\begin{tabular}{|l|l|l|l|l|l|}
\hline Time & EG1 & CBH1 & CBH2 & BG & $\begin{array}{l}\text { Glucose } \\
\text { Conversion }\end{array}$ \\
\hline 24 & 0.5 & 0.00 & 0.32 & 0.18 & 53.4 \\
\hline 48 & 0.52 & 0.00 & 0.26 & 0.22 & 73.5 \\
\hline 72 & 0.52 & 0.00 & 0.24 & 0.24 & 81.0 \\
\hline
\end{tabular}


It was found that the mechanistic model predicts EG1 to be the dominant enzyme in cellulose hydrolysis, followed by CBH2 and CBH1. This follows closely with experimental evidence by many studies on Avicel substrates (Tomme et al., 1988; Nidetzky et al., 1994; Zhang and Lynd 2004). Results are comparable to optimization done by Levine et al. 2011 for glucan conversion in that the optimized enzyme concentrations are similar if it is assumed that EG2 from Taleromyces emersonii, CBH1 and CBH2 from Trichoderma longibrachum is comparable to EG1, CBH1, and CBH2 from Trichoderma reesei. In the model used, as enzyme loading is increased, there is a shift in the optimization for glucan conversion to increase the mass fraction EG1 and decrease CBH2 between 7.5 and $15 \mathrm{mg}$ enzyme/g glucan. This is justified by the model in that as enzyme loading is increased, it is likely that the specific adsorption sites for exo-acting enzymes such as $\mathrm{CBH} 1$ and $\mathrm{CBH} 2$ are more likely to be occupied. Since there is an increase in enzyme concentration but site concentration remains the same at the beginning of hydrolysis, EG1 acts to create additional adsorption sites for exo-acting enzymes which allows cellobiohydrolase enzymes to adsorb to more sites. In this way, EG1 works synergistically with exo-acting enzymes to increase the rate of hydrolysis.

As enzyme loading is increased (>7.5 mg enzyme/g glucan), the change in glucan conversion between mass fractions decreases as long as EG1 mass fraction is greater than 0.2. EG1 is necessary, because it creates sites for the adsorption of exo-acting enzymes. However, at these higher enzyme loadings, hydrolysis occurs rapidly with CBH1 and $\mathrm{CBH} 2$ enzymes. This means that there is less difference between the catalytic rate of CBH1 and CBH2, however it can be shown that higher $\mathrm{CBH} 2$ concentrations will still give higher glucan conversions than CBH1 for modeled Avicel substrates. Some models predict at longer times that $\mathrm{CBH} 1$ would be dominant in an optimization because $\mathrm{CBH} 1$ is more thermostable than CBH2 (Levine et al., 2011). In this model, when the half-life of $\mathrm{CBH} 1$ was increased to 71.4 hours and half-life of $\mathrm{CBH} 2$ was decreased to 34.5 hours (Levine et al., 2011), the model still predicts CBH2 to still be the dominant enzyme after 72 hours. 
It is also worthy to note that at higher time enzyme loadings ( $>15 \mathrm{mg} / \mathrm{g}$ enzyme) our model predicts that the optimization point for glucan conversion contains BG enzymes. This is because the inhibition effect on enzymes increases to the point where it is preferential to lower the inhibition by introducing BG rather than adding additional hydrolyzing enzymes. This prediction is seen to a greater extent in lignocellulose hydrolysis than in cellulose hydrolysis because the model assumes that soluble xylan oligomers have higher inhibitory effects compared with soluble glucan oligomers.

There is an increase in glucose conversion observed as BG enzymes range between 0.1 and 0.3 mass fractions in all cases, which suggests that for cellulose hydrolysis, the optimization of BG enzymes should be within this mass fraction range. This agrees with Zhang et al., 2009 which says that with a $9.1 \mathrm{mg}$ enzyme/g glucan Spezyme CP (cellulase) loading, that $1.45 \mathrm{mg}$ enzyme/g glucan Novozyme 188 (BG) is sufficient to convert cellobiose into glucose which would eliminate oligosaccharide inhibition while 2.9 mg enzyme/g glucan saturates the solution with BG. 


\section{Optimization of Enzymes for Lignocellulose Hydrolysis}

The model was successful in finding an optimization titer for glucan + xylan conversions and glucose + xylose conversions on a modelled lignocellulose substrate. Figure 3.2.A-F shows ternary plots of glucan + xylan conversion and glucose + xylose conversion. Table 3.2.A-F shows the predicted enzyme optimization titers for lignocellulose hydrolysis simulations.
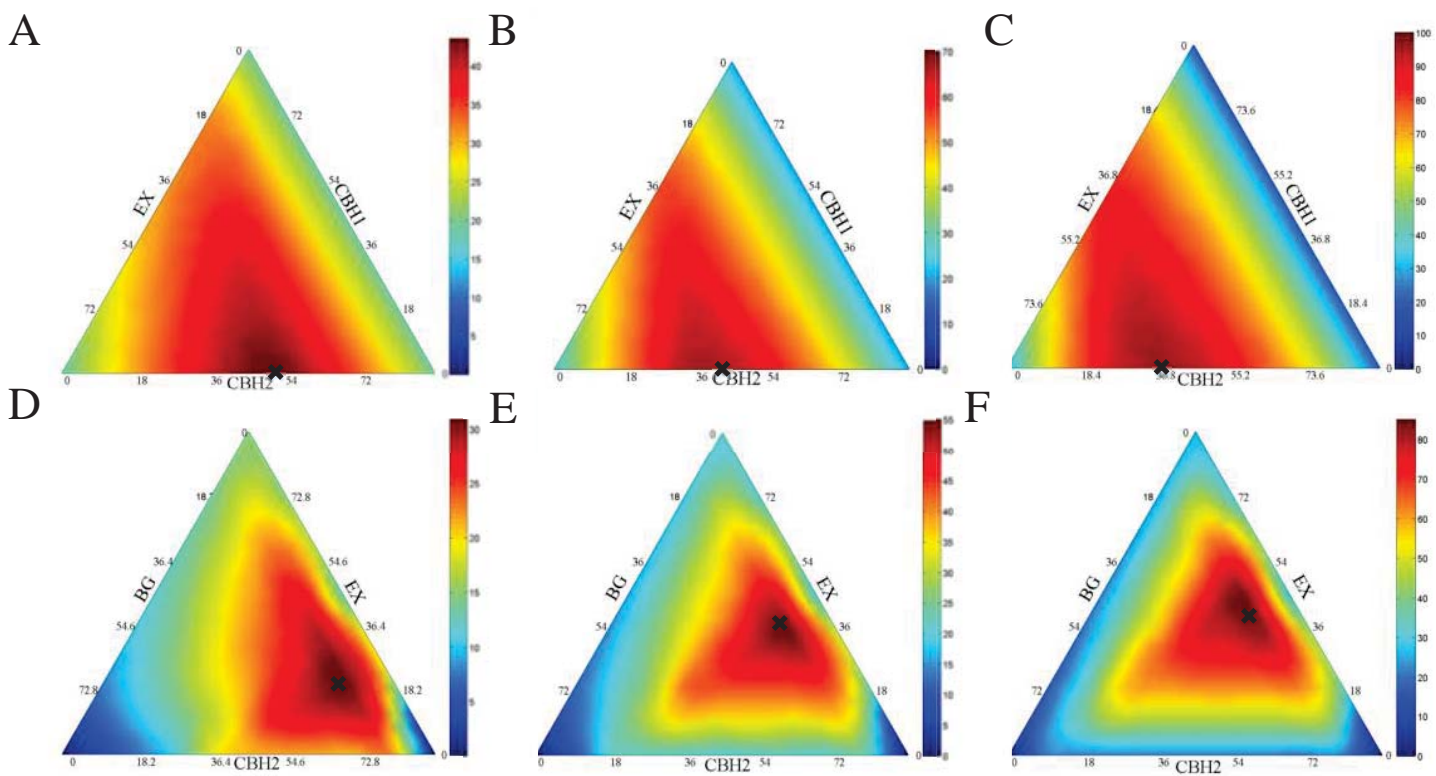

Figure 3.2.A-F Ternary plots of conversion for lignocellulose hydrolysis. Ternary plot predictions of glucan + xylan conversion percent $(\mathrm{A}, \mathrm{B}, \mathrm{C})$ and glucose + xylose conversion percent (D, E, F) at 72 hours with 7.5 (A, D), 15 (B, E), and 30 (C, F) mg enzyme/g glucan. Mass percent of $\mathrm{CBH} 1, \mathrm{CBH}$, and $\mathrm{EX}$ are given for glucan + xylan conversion and mass percent of $\mathrm{CBH} 2, \mathrm{EX}$, and $\mathrm{BG}$ are given for glucose + xylose conversion. Black X marks the optimization point. 
Table 3.2.A-F. Predicted optimized enzyme fractions for lignocellulose hydrolysis. Optimized enzyme mass fractions are presented for the hydrolysis of AFEX pretreated corn stover with predicted optimized glucan + xylan conversion (\%), and predicted optimized glucose + xylose conversion $(\%)$ for a given time of hydrolysis $(24,48,72$ hours). A \& D $7.5 \mathrm{mg}$ enzyme/g glucan, B \& E - $15 \mathrm{mg}$ enzyme/g glucan, C \& F - $30 \mathrm{mg}$ enzyme/g glucan.

A
\begin{tabular}{|l|l|l|l|l|l|l|l|}
\hline Time & EG1 & CBH1 & CBH2 & EX & BG & BX & Glucan + Xylan Conversion (\%) \\
\hline 24 & 0.10 & 0.00 & 0.60 & 0.28 & 0.00 & 0.02 & 27.5 \\
\hline 48 & 0.10 & 0.00 & 0.55 & 0.33 & 0.00 & 0.02 & 39.0 \\
\hline 72 & 0.075 & 0.00 & 0.50 & 0.40 & 0.00 & 0.025 & 43.7 \\
\hline
\end{tabular}

B

\begin{tabular}{|l|l|l|l|l|l|l|l|}
\hline Time & EG1 & CBH1 & CBH2 & EX & BG & BX & Glucan + Xylan Conversion (\%) \\
\hline 24 & 0.08 & 0.00 & 0.55 & 0.35 & 0.00 & 0.02 & 48.7 \\
\hline 48 & 0.08 & 0.00 & 0.45 & 0.45 & 0.00 & 0.02 & 62.6 \\
\hline 72 & 0.07 & 0.00 & 0.40 & 0.50 & 0.00 & 0.03 & 67.1 \\
\hline
\end{tabular}

C

\begin{tabular}{|l|l|l|l|l|l|l|l|}
\hline Time & EG1 & CBH1 & CBH2 & EX & BG & BX & Glucan + Xylan Conversion (\%) \\
\hline 24 & 0.08 & 0.00 & 0.45 & 0.45 & 0.00 & 0.02 & 76.9 \\
\hline 48 & 0.07 & 0.00 & 0.40 & 0.50 & 0.00 & 0.03 & 92.9 \\
\hline 72 & 0.03 & 0.03 & 0.36 & 0.53 & 0.01 & 0.04 & 96.1 \\
\hline
\end{tabular}

D

\begin{tabular}{|l|l|l|l|l|l|l|l|}
\hline Time & EG1 & CBH1 & CBH2 & EX & BG & BX & Glucose + Xylose (\%) \\
\hline 24 & 0.05 & 0.00 & 0.50 & 0.33 & 0.08 & 0.04 & 22.7 \\
\hline 48 & 0.06 & 0.00 & 0.52 & 0.27 & 0.12 & 0.03 & 30.5 \\
\hline 72 & 0.05 & 0.00 & 0.50 & 0.29 & 0.12 & 0.04 & 33.4 \\
\hline
\end{tabular}

$\mathbf{E}$

\begin{tabular}{|l|l|l|l|l|l|l|l|}
\hline Time & EG1 & CBH1 & CBH2 & EX & BG & BX & Glucose + Xylose (\%) \\
\hline 24 & 0.06 & 0.00 & 0.53 & 0.30 & 0.08 & 0.03 & 41.4 \\
\hline 48 & 0.06 & 0.00 & 0.45 & 0.36 & 0.10 & 0.03 & 53.1 \\
\hline 72 & 0.05 & 0.00 & 0.41 & 0.39 & 0.12 & 0.03 & 56.3 \\
\hline
\end{tabular}

$\mathbf{F}$

\begin{tabular}{|l|l|l|l|l|l|l|l|}
\hline Time & EG1 & CBH1 & CBH2 & EX & BG & BX & Glucose + Xylose (\%) \\
\hline 24 & 0.07 & 0.00 & 0.44 & 0.35 & 0.10 & 0.04 & 68.7 \\
\hline 48 & 0.06 & 0.00 & 0.37 & 0.44 & 0.10 & 0.03 & 83.4 \\
\hline 72 & 0.06 & 0.00 & 0.35 & 0.46 & 0.10 & 0.03 & 87.1 \\
\hline
\end{tabular}


The predicted dominant enzymes in glucan + xylan conversion are CBH2, followed by EX and EG1. The predicted dominant enzymes in glucose + xylose conversion are $\mathrm{CBH} 2$, followed by EX and BG. It is worth noting that CBH1 has a mass fraction of 0.00 for all optimized enzyme concentrations in Avicel and AFEX pretreated corn stover except at high enzyme loading (30 mg enzyme/g substrate) and long hydrolysis times (72 hours).

EG1 is predicted to be lower while EX is predicted to be higher in the AFEX pretreated corn stover than in other models (Banerjee et al., 2010a; Banerjee et al., 2010b; Gao et al., 2010). This may be because EG1 has a high adsorption constant relative to EX. This would lead to an increase in catalytic rate, so less EG1 is needed to hydrolyze the same amount of substrate. Also, EG1 has the purpose in the model of creating sites for CBH1 and $\mathrm{CBH} 2$, while EX purpose in the model is to be the sole enzyme to hydrolyze xylan into soluble oligomers, which means there will need to be more EX in order to accomplish this singlehandedly.

$\mathrm{CBH} 2$ is much higher than $\mathrm{CBH} 1$ in the optimized mass fractions, however it may be a good approximation to assume that the amount of $\mathrm{CBH} 2$ should represent the sum of $\mathrm{CBH} 1$ and $\mathrm{CBH} 2$ enzyme types, because these enzymes have the same purpose of hydrolyzing the substrate into cellobiose, only different sites of action. Where CBH1 acts on the reducing end of the glucan chain, $\mathrm{CBH} 2$ acts on the non-reducing end of the glucan chain. It can be shown that when $\mathrm{CBH} 1$ and $\mathrm{CBH} 2$ have the same parameters but their original sites, the resulting hydrolysis yield is the same. The constants used in lignocellulose hydrolysis come from the hydrolysis of Avicel, which is known to have a higher catalytic rate for CBH2 than for CBH1 (Zhang and Lynd, 2004). However, for the hydrolysis of lignocellulose, it is true that $\mathrm{CBH} 1$ has been predicted to be in larger in composition in optimized enzyme fractions than CBH2 (Banerjee et al., 2010a; Banerjee et al., 2010b; Gao et al., 2010). Since it was modeled from Avicel though, CBH2 still has the higher catalytic rate. 
With reduced cellulase adsorption parameters it is possible to achieve results more similar to previously published mechanistic models. By decreasing the adsorption parameters for cellulases by dividing them by more than 50 , the optimization point found in literature of 0.22 EG1, 0.22 CBH1, 0.05 CBH1, 0.30 EX, 0.15 BG, and 0.06 BX (Banerjee et al., 2010b) shows more glucose conversion at $15 \mathrm{mg} / \mathrm{g}$ glucan enzyme loading than the optimization point found by this model of 0.06 EG1, 0 CBH1, 0.41 CBH2, 0.39 EX, 0.12 BG, 0.03 BX. This indicates that accurate adsorption parameters to specific lignocellulose substrates sites are key to predicting a realistic optimization enzyme composition.

In the model used for optimization, no single source could be found for all required sitespecific parameters so a collection of sources were used. This may contribute to the lack of consistency considering EG1, CBH1, and CBH2 with statistically designed experiments on AFEX pretreated corn stover. Also, the magnitude of conversion disagrees with statistically designed experiments, however this was expected because Pichia pastoris was used to express proteins this may lead to abnormal glycolysation (Banerjee et al., 2010b). This may have a negative effect on the activity of hydrolyzing enzymes. In this model, the activity of enzymes is expressed from experiments using enzymes directly produced by Trichoderma reesei and Aspergillus niger which is why conversion yields are comparable to those of commercial enzymes. 


\section{Simulation of Enzyme Addition Time Effects}

After the optimized glucose conversion results were obtained for Avicel, and AFEX pretreated corn stover, BG and BX were modeled as being added into solution at 0, 24, and 48 hours. The optimized glucose conversion and xylose conversion titers were used at an enzyme loading of 15 mg enzyme/g glucan for 72 hours. Figure 3.4 shows Avicel hydrolysis predictions when BG is added at a later time, Figure 3.5 shows AFEX pretreated corn stover predictions when BG is added at a later time, and Figure 3.6 shows AFEX pretreated corn stover predictions when BX is added at a later time.

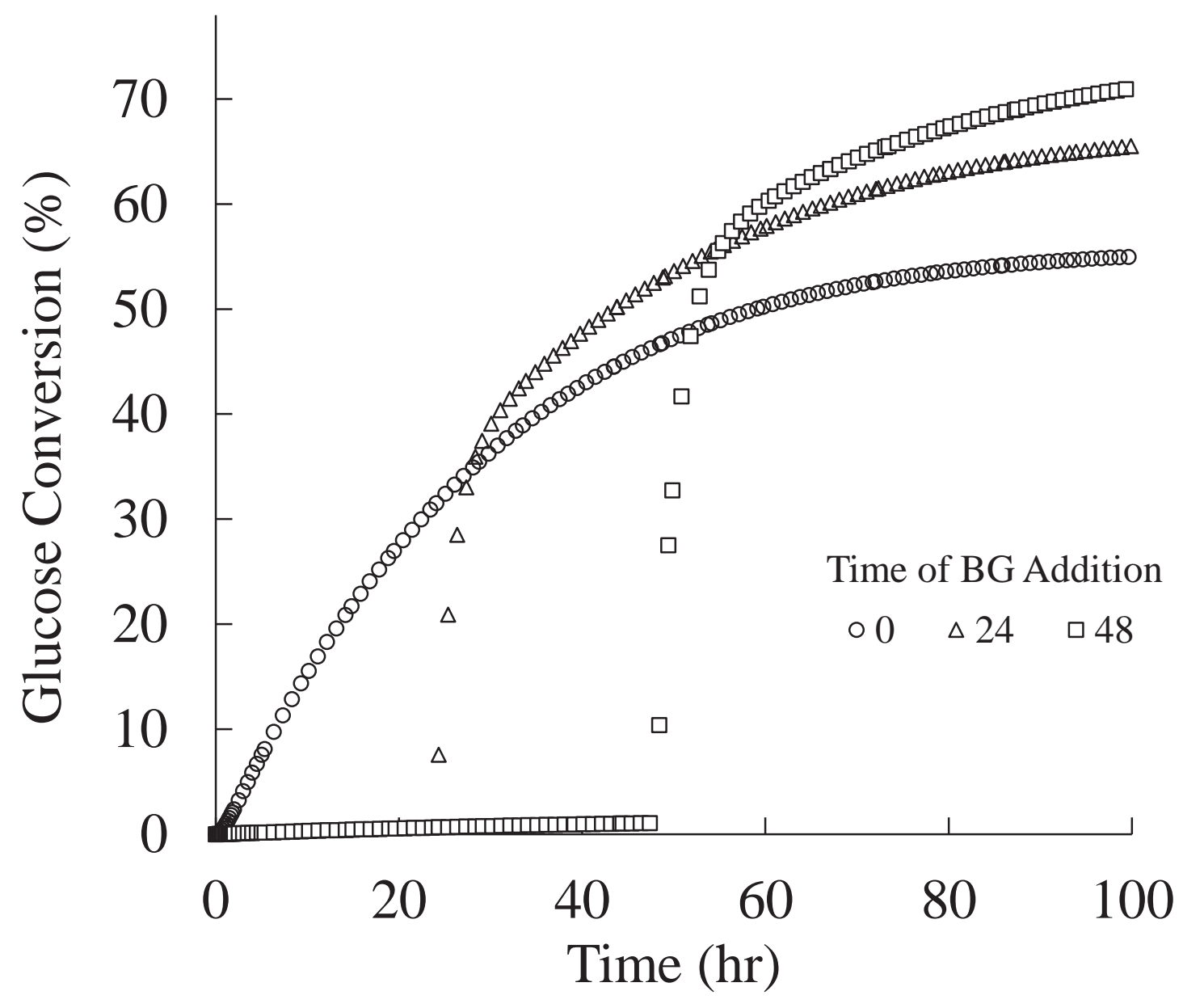

Figure 3.3. Glucose conversion after addition of BG for cellulose hydrolysis. BG was modeled for the hydrolysis of Avicel as being added into solution at 0,24 , and 48 hours for the optimized glucose conversion titer at $15 \mathrm{mg}$ enzyme/g glucan and 72 hours. 


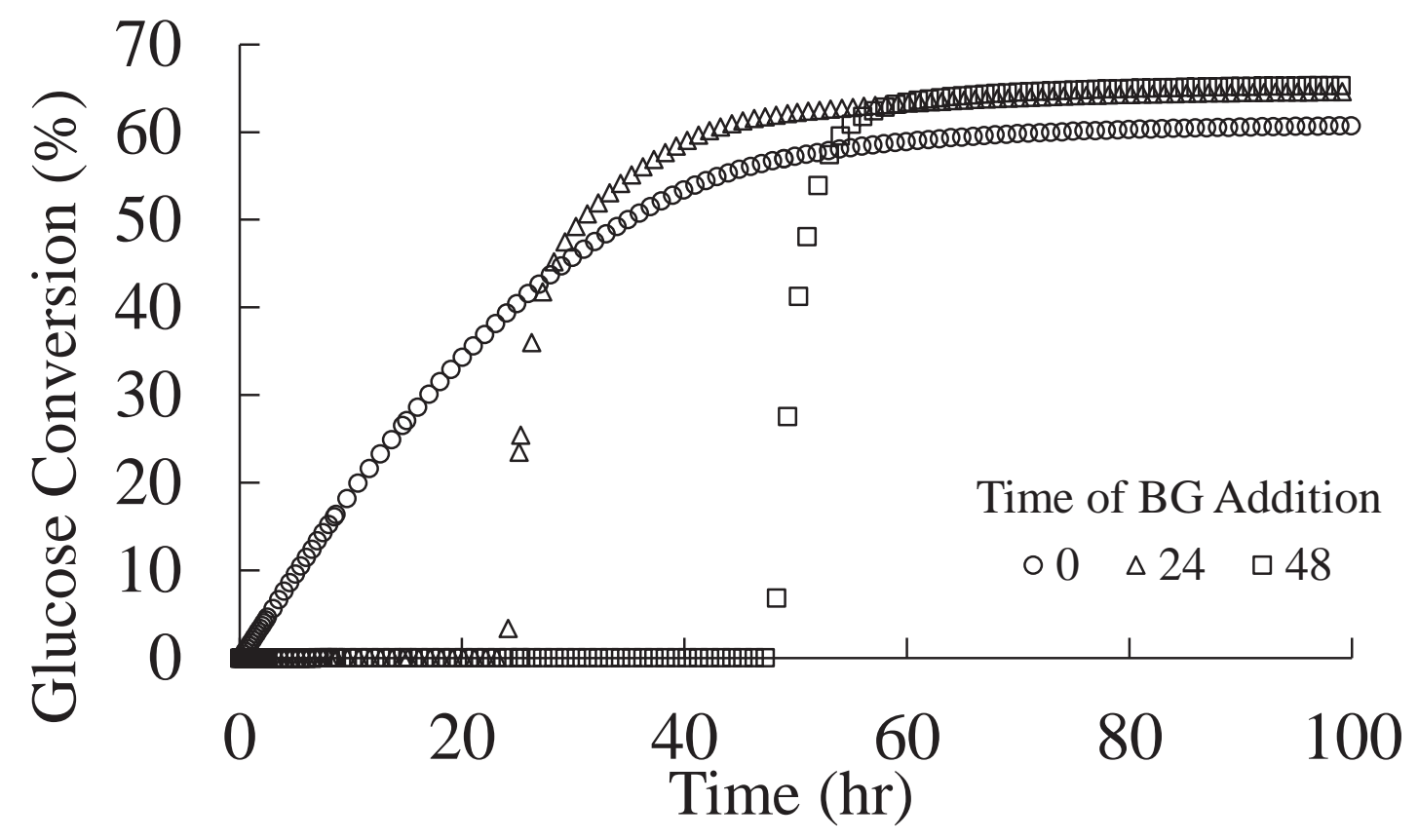

Figure 3.4. Glucose conversion after addition of BG for lignocellulose hydrolysis. BG was modeled for the hydrolysis of AFEX pretreated corn stover as being added into solution at 0,24 , and 48 hours for the optimized glucose conversion titer at $15 \mathrm{mg}$ enzyme/g glucan and 72 hours.

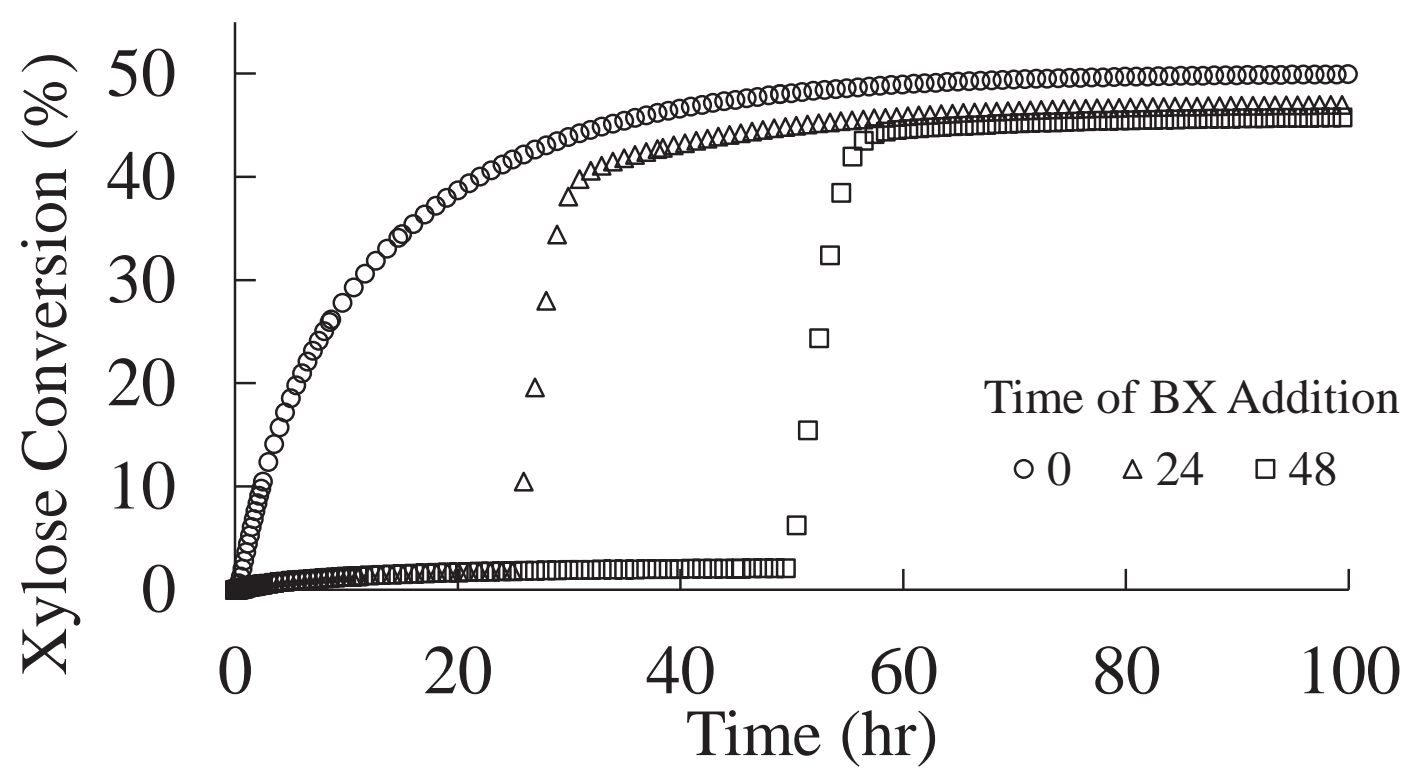

Figure 3.5. Xylose conversion after addition of BX for lignocellulose hydrolysis. BX was modeled for the hydrolysis of AFEX pretreated corn stover as being added into solution at 0, 24, and 48 hours for the optimized glucose + xylose conversion titer at $15 \mathrm{mg}$ enzyme/g glucan and 72 hours. 
For cellulose hydrolysis, predictions indicate that there is an advantage to adding BG later in the hydrolysis process. When added at 24 hours there is an increase in glucose conversion after 100 hours to $63 \%$ compared to when BG was added at 0 hours (52\%). The model indicates there is still improvement from 24 hours in the glucose yield if BG is added at 48 hours (70\%).

For lignocellulose hydrolysis, predictions indicate there is an advantage of adding BG later as well. There was an increase found when BG was added after 24 hours (61\%) compared with when BG was added at 0 hours (57\%). Results indicate that adding BG later than this does not make a significant difference in glucose concentration. It was found that there is less significant of a change in the glucose conversion seen in lignocellulose hydrolysis compared with cellulose hydrolysis. Since there is little soluble oligosaccharides at the start of hydrolysis, there is little need for BG at the beginning of hydrolysis. BG short half-life coupled with its lack of substrate early in hydrolysis mean that there may be an advantage in delaying the time of entry of BG.

For lignocellulose hydrolysis, predictions indicate that there is a disadvantage to adding BX later. A decrease in xylose was observed if BX was added at 24 and 48 hours relative to being added at the start of hydrolysis. Since most xylan is present on outer layers of an SAC, the production rate of soluble xylo-oligomers at the start of hydrolysis is high. These soluble oligomers are also stronger inhibitors of EG1, CBH1, and CBH2 which would decrease the enzyme's hydrolysis rate. Therefore, results indicate that it is important to have BX in solution at the beginning of hydrolysis because of the high production of soluble xylo-oligomers at the start of hydrolysis. BX is necessary to hydrolyze the soluble xylo-oligomers quickly to prevent the inhibition of enzymes. 


\section{Conclusions}

The novel mechanistic model for the simultaneous hydrolysis of cellulose and hemicellulose formulated predictions of glucose and xylose yields for Avicel and AFEX pretreated corn stover. In a four enzyme simulation with an Avicel substrate, the model predicts the optimal enzyme concentration for glucose conversion depending on the enzyme loading. EG1 was predicted to be the dominant enzyme in cellulose hydrolysis, closely followed by $\mathrm{CBH} 2$. This is expected as these enzymes have a higher conversion rate on Avicel and are two of the most important enzymes for hydrolysis of cellulose (Zhang and Lynd, 2006).

In the six enzyme simulation with an AFEX pretreated corn stover substrate, $\mathrm{CBH} 2$ was predicted to be the dominant enzyme, followed by EX. It is worth mentioning that during hydrolysis simulations, the optimal enzyme concentrations varied greatly on substrate composition, degree of polymerization, and surface accessibility. Therefore, it is a safe assumption that the model will predict different optimum enzyme compositions for different lignocellulose substrates.

Results suggests that as time and enzyme loading are increased for cellulose substrate, the importance of higher EG1 concentrations is also increased. This may be because initially exo-acting enzymes ( $\mathrm{CBH} 1$ and $\mathrm{CBH} 2$ ) consume substrate at an accelerated rate. However, towards the end of hydrolysis these exo-acting enzymes run out of site-specific substrate. EG1 acts in the model to lower the degree of polymerization by cutting random $\beta$-glycosidic bonds. This would create more sites for exo-acting enzymes to adsorb and catalyze reactions, which would increase the cellulose conversion. Model predictions indicate that by adding BG later in hydrolysis, this would increase the generation of glucose product. This may be because glucan oligosaccharides only have significant concentration after the first few hours of hydrolysis.

We created a novel mechanistic tool for the optimization of cellulose and lignocellulose which illustrates the importance of the relationship between enzymes and substrate, and 
can predict yields of monosaccharides and oligosaccharides for various compositions of hydrolyzing enzymes. This model is intended to be a tool to predict yields from enzyme titers for the hydrolysis of lignocellulose, and to optimize enzyme yields based on the substrate modelled. 


\section{Future Work}

Results do not accurately predict experimental results for optimizations especially for lignocellulose hydrolysis. This is due to a lack of literature consensus for parameters from different sources; lack of information on specific adsorption and activity parameters to specific substrates; lack of accounting for secondary functions of enzymes; and lack of substrate information necessary for modeling.

New adsorption and kinetic parameters should be specific to the substrate hydrolyzed such as using adsorption and kinetic parameters specifically for the hydrolysis of AFEX pretreated corn stover. This was a problem that contributed to the model reporting 0.00 mass fraction of $\mathrm{CBH} 1$ even though experimental evidence suggests the optimization of AFEX pretreated corn stover should contain significant CBH1 (Banerjee et al. 2010). Adsorption and kinetic parameters for enzymes could be added for secondary sites of enzymes or sites that do not represent the enzyme's main function. For example, CBH1 could hydrolyze a soluble oligosaccharide into glucose, EG1 could adsorb to a xylan chain and hydrolyze a bond.

A model could be made to predict pretreatment parameters for lignocellulose hydrolysis. More information about the substrate, such as percentage of hemicellulose on the surface of the substrate, surface area of the substrate, and crystallinity of cellulose could be generated from this model and would improve the accuracy of the optimization. Lastly, the effects of lignin, another main compound in lignocellulose, could be added to the model to take into account the significant substrate inhibition caused by nonproductive adsorption to lignin. 


\section{References}

Banerjee G, Car S, Scott-Craig JS, Borrusch MS, Aslam N, Walton JD. 2010a. Synthetic enzyme mixtures for biomass deconstruction: Production and optimization of a core set. Biotechnol Bioeng 106:707-720.

Banerjee G, Car S, Scott-Craig JS, Borrusch MS, Bongers M, Walton JD. 2010b.

Synthetic multi component enzyme mixtures for deconstruction of lignocellulosic biomass. Bioresour Technol 101(23):9097-105.

Berlin A, Maximenko V, Gilkes N, Saddler J. 2006. Optimization of Enzyme Complexes for Lignocellulose Hydrolysis. Biotechnol Bioeng 97:287-296.

Billard H, Faraj A, Ferreira NL, Menir S, Heiss-Blanquet S. 2012. Optimization of a synthetic mixture composed of major Trichoderma reesei enzymes for the hydrolysis of steam-exploded wheat straw. Biotechnol Biofuels 5:9.

Cherubini F, Bird ND, Cowie A, Jungmeier G, Schlamadinger B, Woess-Gallasch S. 2009. Energy- and greenhouse gas-based LCA of biofuel and bioenergy systems: Key issues, ranges and recommendations. Resources, Conservation and Recycling 53:434447.

Gao D, Chundawat SP, Krishnan C, Balan V, Dale BE. 2010. Mixture optimization of six core glycosyl hydrolases for maximizing saccharification of ammonia fiber explosion (AFEX) pretreated corn stover. Bioresour Technol 101:2770-2781.

$\mathrm{Gu}$ T, Held MA, Faik A. 2013. Supercritical $\mathrm{CO}_{2}$ and ionic liquids for the pretreatment of lignocellulosic biomass in bioethanol production. Environmental Technology 34:13-14. Hakulinen N, Turunen O, Janis J, Leisola M, Rouvinen J. Three-dimensional structures of thermophilic $\beta-1,4$-xylanases from Chaetomium thermophilum and Nonomuraea flexuosa: Comparison of twelve xylanases in relation to their thermal stability. Eur J Biochem 270:1399-1412.

Klein-Marcuschamer D, Oleskowicz-Popiel P, Simmons B, Blanch HW. 2012. The challenge of enzyme cost in the production of lignocellulosic biofuels. Biotechnol Bioeng 109:1083-1087. 
Kumar P, Barrett DM, Delwiche MJ, Stroeve P. 2009. Methods for pretreatment of lignocellulosic biomass for efficient hydrolysis and biofuel production. Ind Eng Chem Res 48:3713-3729.

Levine SE, Fox JM, Blanch HW, Clark DS. 2010. A Mechanistic Model of the Enzymatic Hydrolysis of Cellulose. Biotechnol Bioeng 107:37-51.

Levine SE, Fox JM, Clark DS, Blanch HW. 2011. A Mechanistic Model for Rational design of optimal cellulose mixtures. Biotechnol Bioeng 108:2561-2570.

Morales G, Melero JA, Iglesias J, Paniagua M. 2014. Advanced Biofuels for Lignocellulosic Biomass. J Adv Chem Eng 4:e101.

Nidetzky B, Steiner W, Claeyssens W. 1994. Cellulose hydrolysis by the cellulases from Trichoderma reesei: adsorption of two cellobiohydrolases, two endocellulases and their core proteins on filter paper and their relation to hydrolysis. Biochem J 303:817-823. Tomme P, Van Tilbeurgh H, Pettersson G, Van Damme J, Vandekerckhove J, Knowles J, Teeri T, Claeyssens M. 1988. Studies of the cellulolytic system of Trichoderma reesei QM 9414. Eur J Biochem 170:575-581.

Singhania RR, Saini JK, Saini R, Adsul M, Mathur A, Gupta R, Tuli DK. 2014.

Bioethanol production from wheat straw via enzymatic route employing Penicillium janthinellum cellulases. Bioresour Technol 169:490-495.

Qing Q, Wyman CE. 2011. Supplementation with xylanase and $\beta$-xylosidase to reduce xylo-oligomer and xylan inhibition of enzymatic hydrolysis of cellulose and pretreated corn stover. Biotechnology for Biofuels 4:18.

Yang B, Dai Z, Ding SY, Wyman CE. 2011. Enzymatic hydrolysis of cellulosic biomass: a review. Biofuels 2:421-450.

Yang B, Willies DM, Wyman CE. 2006. Changes in the enzymatic hydrolysis rate of Avicel cellulose with conversion. Biotechnol Bioeng 94(6):1122-8.

Ye Z, Hatfield KM, Berson RE. 2012. Deactivation of individual cellulase components. Bioresour Technol 106:133-137.

Yu Z, Gwak KS, Treasure T, Jameel H, Chang H, Park S. 2014. Effect of Lignin

Chemistry on the Enzymatic Hydrolysis of Woody Biomass. Chem Sus Chem 7(7):19421950. 
Zhang M, Su R, Qi W, He Z. 2009. Enhanced enzymatic hydrolysis of lignocellulose by optimizing enzyme complexes. Appl Biochem Biotechnol 160:1407-1414.

Zhang YHP, Lynd LR. 2004. Toward an Aggregated Understanding of Enzymatic Hydrolysis of Cellulose: Noncomplexed Cellulase Systems. Biotechnol Bioeng 88:797824.

Zhang YHP, Lynd LR. 2006. A functionally based model for the hydrolysis of cellulose by fungal cellulase. Biotechnol Bioeng 94:888-898.

Zhang Y, Bingquian X, Zhou W. 2014. On a novel mechanistic model for simultaneous enzymatic hydrolysis of cellulose and hemicellulose considering morphology. Biotechnol Bioeng 111:1767-1781.

Zhao X, Zhang L, Liu D. 2012. Biomass recalcitrance. Part I: the chemical compositions and physical structures affecting the enzymatic hydrolysis of lignocellulose: a review. Biofuels, Bioprod Bioref 6:465-482.

Zhou W, Schuttler HB, Hao Z, Xu Y. 2009. Cellulose hydrolysis in evolving substrate morphologies I: A general modeling formalism. Biotechnol Bioeng 104:261-274. Zhou W, Hao Z, Xu Y, Schuttler HB. 2009. Cellulose hydrolysis in evolving substrate morphologies II: numerical results and analysis. Biotechnol Bioeng 104:275-289. 


\section{Appendix: Simulation Parameters}

Table A.1. Substrate parameters - for simulation of Avicel hydrolysis and AFEX pretreated corn stover hydrolysis. Note that DP Hemicellulose is undefined for Avicel hydrolysis because for Avicel $\bar{\Phi}_{\mathrm{V}, \mathrm{Xyl}}^{0}=0$.

\begin{tabular}{|c|l|l|l|l|l|}
\hline \multicolumn{2}{|l|}{ Avicel } & \multicolumn{2}{l|}{ AFEX pretreated Corn Stover } \\
\hline Parameter & Value & Ref. & Parameter & Value & Ref. \\
\hline$\overline{\mathrm{F}}_{\mathrm{A}}^{(0)}$ & 0.006 & $\begin{array}{l}\text { Zhou et al., } \\
\text { 2009b; Zhang } \\
\text { and Lynd } \\
\text { 2006 }\end{array}$ & $\overline{\mathrm{F}}_{\mathrm{A}}^{(0)}$ & 0.1051 & $\begin{array}{l}\text { Zhang et } \\
\text { al, 2014 }\end{array}$ \\
\hline $\bar{\Phi}_{\mathrm{M}, \text { Xyl }}^{0}$ & 0 & Assumed & $\bar{\Phi}_{\text {M,Xyl }}^{0}$ & 0.55 & $\begin{array}{l}\text { Zhang et } \\
\text { al., 2014 }\end{array}$ \\
\hline DP Cellulose & 300 & $\begin{array}{l}\text { Zhou et al., } \\
\text { 2009b; Zhang } \\
\text { and Lynd } \\
\text { 2006 }\end{array}$ & DP Cellulose & 6800 & $\begin{array}{l}\text { Kumar and } \\
\text { Wyman }\end{array}$ \\
\hline $\begin{array}{l}\text { DP } \\
\text { Hemicellulose }\end{array}$ & N/A & $\begin{array}{l}\text { Assumed } \\
\text { DP }\end{array}$ & Hemicellulose & 200 & Assumed \\
\hline
\end{tabular}

Table A.2. Adsorption parameters - this represents the equilibrium adsorption constant of enzymes EG1, CBH1, CBH2, EX to sites N, X, Y for cellulose and xylan. The parameters for cellulases were from an experiment with filter paper (Nidetzky et al. 1994) and the parameters for EX were from the publication of the model (Zhang et al. 2014).

\begin{tabular}{|c|c|c|}
\hline Parameter & $\begin{array}{l}\text { Value } \\
\text { (L/mmol) }\end{array}$ & Ref. \\
\hline $\mathrm{L}_{\mathrm{EG}, \mathrm{N}, \mathrm{Glu}}, \mathrm{L}_{\mathrm{EG} 1, \mathrm{X}, \mathrm{Glu}}, \mathrm{L}_{\mathrm{EG} 1, \mathrm{Y}, \mathrm{Glu}}$ & 560 & \multirow{8}{*}{$\begin{array}{l}\text { Nidetzky et } \\
\text { al., } 1994\end{array}$} \\
\hline $\mathrm{L}_{\mathrm{EG} 1, N, X y l}, \mathrm{~L}_{\mathrm{EG}, \mathrm{X}, \mathrm{Xyl}}, \mathrm{L}_{\mathrm{EG}, \mathrm{Y}, \mathrm{Xyl}}$ & 0 & \\
\hline $\mathrm{L}_{\mathrm{CBH} 2, \mathrm{~N}, \mathrm{Glu}}, \mathrm{L}_{\mathrm{CBH} 2, \mathrm{Y}, \mathrm{Glu}}$ & 0 & \\
\hline $\mathrm{L}_{\mathrm{CBH} 2, \mathrm{X}, \mathrm{Glu}}$ & 950 & \\
\hline $\mathrm{L}_{\mathrm{CBH} 2, \mathrm{~N}, \mathrm{Xyl}}, \mathrm{L}_{\mathrm{CBH} 2, \mathrm{X}, \mathrm{Xyl}}, \mathrm{L}_{\mathrm{CBH} 2, \mathrm{Y}, \mathrm{Xyl}}$ & 0 & \\
\hline $\mathrm{L}_{\mathrm{CBH} 1, \mathrm{~N}, \mathrm{Glu}}, \mathrm{L}_{\mathrm{CBH} 1, \mathrm{X}, \mathrm{Glu}}$ & 0 & \\
\hline $\mathrm{L}_{\mathrm{CBH} 1, \mathrm{Y}, \mathrm{Glu}}$ & 1410 & \\
\hline $\mathrm{L}_{\mathrm{CBH} 1, \mathrm{~N}, \mathrm{Xyl}}, \mathrm{L}_{\mathrm{CBH} 1, \mathrm{X}, \mathrm{Xyl}}, \mathrm{L}_{\mathrm{CBH} 1, \mathrm{Y}, \mathrm{Xyl}}$ & 0 & \\
\hline $\mathrm{L}_{\mathrm{EX}, \mathrm{N}, \mathrm{Glu}}, \mathrm{L}_{\mathrm{EX}, \mathrm{X}, \mathrm{Glu}}, \mathrm{L}_{\mathrm{EX}, \mathrm{Y}, \mathrm{Glu}}$ & 0 & \multirow{2}{*}{$\begin{array}{l}\text { Zhang et } \\
\text { al., } 2014\end{array}$} \\
\hline $\mathrm{L}_{\mathrm{EX}, \mathrm{N}, \mathrm{Xyl}}, \mathrm{L}_{\mathrm{EX}, \mathrm{X}, \mathrm{Xyl}}, \mathrm{L}_{\mathrm{EX}, \mathrm{Y}, \mathrm{Xyl}}$ & 0.574 & \\
\hline
\end{tabular}


Table A.3. Activity parameters - this represents the specific activity of the enzyme-substrate complex of EG1, CBH2, CBH1, EX on sites N, X, Y with glucan or xylan chains.

\begin{tabular}{|c|c|c|}
\hline Parameter & $\begin{array}{l}\text { Value (mmol bond } \\
\text { cleaved mmol enzyme } \\
\min ^{-1} \text { ) }\end{array}$ & Ref. \\
\hline$\gamma_{\mathrm{EG} 1, \mathrm{~N}, \mathrm{Glu}}, \gamma_{\mathrm{EG} 1, \mathrm{X}, \mathrm{Glu}}, \gamma_{\mathrm{EG} 1, \mathrm{Y}, \mathrm{Glu}}$ & 2.475 & \multirow{2}{*}{$\begin{array}{l}\text { Zhang and Lynd, } \\
2004\end{array}$} \\
\hline$\gamma_{\mathrm{EG} 1, \mathrm{~N}, \mathrm{Xyl}}, \gamma_{\mathrm{EG} 1, \mathrm{X}, \mathrm{Xyl}}, \gamma_{\mathrm{EG} 1, \mathrm{Y}, \mathrm{Xyl}}$ & 0 & \\
\hline$\gamma_{\mathrm{CBH} 2, \mathrm{~N}, \mathrm{Glu}}, \gamma_{\mathrm{CBH} 2, \mathrm{Y}, \mathrm{Glu}}$ & 0 & \multirow{6}{*}{$\begin{array}{l}\text { Zhang and Lynd, } \\
2006\end{array}$} \\
\hline$\gamma_{\mathrm{CBH} 2, \mathrm{X}, \mathrm{Glu}}$ & 9.28 & \\
\hline$\gamma_{\mathrm{CBH} 2, \mathrm{~N}, \mathrm{Xyl}}, \gamma_{\mathrm{CBH} 2, \mathrm{X}, \mathrm{Xyl}}, \gamma_{\mathrm{CBH} 2, \mathrm{Y}, \mathrm{Xyl}}$ & 0 & \\
\hline$\gamma_{\mathrm{CBH} 1, \mathrm{~N}, \mathrm{Glu}}, \gamma_{\mathrm{CBH} 1, \mathrm{X}, \mathrm{Glu}}$ & 0 & \\
\hline$\gamma_{\mathrm{CBH} 1, \mathrm{Y}, \mathrm{Glu}}$ & 5.44 & \\
\hline$\gamma_{\mathrm{CBH} 1, \mathrm{~N}, \mathrm{Xyl}}, \gamma_{\mathrm{CBH} 1, \mathrm{X}, \mathrm{Xyl}}, \gamma_{\mathrm{CBH} 1, \mathrm{Y}, \mathrm{Xyl}}$ & 0 & \\
\hline$\gamma_{\mathrm{EX}, \mathrm{N}, \mathrm{Glu}}, \gamma_{\mathrm{EX}, \mathrm{X}, \mathrm{Glu}}, \gamma_{\mathrm{EX}, \mathrm{Y}, \mathrm{Glu}}$ & 0 & \multirow[t]{2}{*}{ Zhang et al., 2014} \\
\hline$\gamma_{\mathrm{EX}, \mathrm{N}, \mathrm{Xyl}}, \gamma_{\mathrm{EX}, \mathrm{X}, \mathrm{Xyl}}, \gamma_{\mathrm{EX}, \mathrm{Y}, \mathrm{Xyl}}$ & 8.771 & \\
\hline
\end{tabular}

Table A.4. Beta-enzyme parameters

\begin{tabular}{|c|c|c|c|c|c|}
\hline Parameter & $\begin{array}{l}\text { Value } \\
(1 / \mathrm{mM})\end{array}$ & Reference & Parameter & $\begin{array}{c}\text { Value } \\
\text { (mmol bond } \\
\text { cleaved } \\
\text { mmol } \\
\text { enzyme } \\
\min ^{-1} \text { ) }\end{array}$ & Reference \\
\hline $\mathrm{I}_{\mathrm{BG}, \mathrm{Glu}}(1)$ & 0.294 & \multirow{5}{*}{$\begin{array}{l}\text { Zhang et } \\
\text { al., } 2014\end{array}$} & $\gamma_{\mathrm{BG}, \mathrm{Glu}}(1)$ & 0 & \multirow{5}{*}{$\begin{array}{l}\text { Zhang et } \\
\text { al., } 2014\end{array}$} \\
\hline $\mathrm{I}_{\mathrm{BG}, \mathrm{Glu}}(2)$ & 1.136 & & $\gamma_{\mathrm{BG}, \mathrm{Glu}}(2)$ & 1897 & \\
\hline $\mathrm{I}_{\mathrm{BG}, \mathrm{Glu}}(3)$ & 3.846 & & $\gamma_{\mathrm{BG}, \mathrm{Glu}}(3)$ & 1738.9 & \\
\hline $\mathrm{I}_{\mathrm{BG}, \mathrm{Glu}}(4)$ & 4.000 & & $\gamma_{\mathrm{BG}, \mathrm{Glu}}(4)$ & 1422.8 & \\
\hline $\mathrm{I}_{\mathrm{BG}, \mathrm{Glu}}(5)$ & 2.174 & & $\gamma_{\mathrm{BG}, \mathrm{Glu}}(5)$ & 895.8 & \\
\hline
\end{tabular}




\begin{tabular}{|c|c|c|c|}
\hline $\mathrm{I}_{\mathrm{BG}, \mathrm{Glu}}(6)$ & 1.449 & $\gamma_{\mathrm{BG}, \mathrm{Glu}}(6)$ & 843.1 \\
\hline $\mathrm{I}_{\mathrm{BG}, \mathrm{Xyl}}(1)$ & 0.417 & $\gamma_{\mathrm{BG}, \mathrm{Xyl}}(1)$ & 0 \\
\hline $\mathrm{I}_{\mathrm{BG}, \mathrm{Xyl}}(2)$ & 0 & $\gamma_{\mathrm{BG}, \mathrm{Xyl}}(2)$ & 0 \\
\hline $\mathrm{I}_{\mathrm{BG}, \mathrm{Xyl}}(3)$ & 0 & $\gamma_{\mathrm{BG}, \mathrm{Xyl}}(3)$ & 0 \\
\hline $\mathrm{I}_{\mathrm{BG}, \mathrm{Xyl}}(4)$ & 0 & $\gamma_{\mathrm{BG}, \mathrm{Xyl}}(4)$ & 0 \\
\hline $\mathrm{I}_{\mathrm{BG}, \mathrm{Xyl}}(5)$ & 0 & $\gamma_{\mathrm{BG}, \mathrm{Xyl}}(5)$ & 0 \\
\hline $\mathrm{I}_{\mathrm{BG}, \mathrm{Xyl}}(6)$ & 0 & $\gamma_{\mathrm{BG}, \mathrm{Xyl}}(6)$ & 0 \\
\hline $\mathrm{I}_{\mathrm{BX}, \mathrm{Glu}}(1)$ & 0.294 & $\gamma_{\mathrm{BX}, \mathrm{Glu}}(1)$ & 0 \\
\hline $\mathrm{I}_{\mathrm{BX}, \mathrm{Glu}}(2)$ & 0 & $\gamma_{\mathrm{BX}, \mathrm{Glu}}(2)$ & 0 \\
\hline $\mathrm{I}_{\mathrm{BX}, \mathrm{Glu}}(3)$ & 0 & $\gamma_{\mathrm{BX}, \mathrm{Glu}}(3)$ & 0 \\
\hline $\mathrm{I}_{\mathrm{BX}, \mathrm{Glu}}(4)$ & 0 & $\gamma_{\mathrm{BX}, \mathrm{Glu}}(4)$ & 0 \\
\hline $\mathrm{I}_{\mathrm{BX}, \mathrm{Glu}}(5)$ & 0 & $\gamma_{\mathrm{BX}, \mathrm{Glu}}(5)$ & 0 \\
\hline $\mathrm{I}_{\mathrm{BX}, \mathrm{Glu}}(6)$ & 0 & $\gamma_{\mathrm{BX}, \mathrm{Glu}}(6)$ & 0 \\
\hline $\mathrm{I}_{\mathrm{BX}, \mathrm{Glu}}(1)$ & 0.417 & $\gamma_{\mathrm{BX}, \mathrm{Xyl}}(1)$ & 0 \\
\hline $\mathrm{I}_{\mathrm{BX}, \mathrm{Xyl}}(2)$ & 2.500 & $\gamma_{\mathrm{BX}, \mathrm{Xyl}}(2)$ & 1897 \\
\hline $\mathrm{I}_{\mathrm{BX}, \mathrm{Xyl}}(3)$ & 5.00 & $\gamma_{\mathrm{BX}, \mathrm{Xyl}}(3)$ & 1250.3 \\
\hline $\mathrm{I}_{\mathrm{BX}, \mathrm{Xyl}}(4)$ & 6.250 & $\gamma_{\mathrm{BX}, \mathrm{Xyl}}(4)$ & 1164.1 \\
\hline $\mathrm{I}_{\mathrm{BX}, \mathrm{Xyl}}(5)$ & 10.000 & $\gamma_{\mathrm{BX}, \mathrm{Xyl}}(5)$ & 1293.4 \\
\hline $\mathrm{I}_{\mathrm{BX}, \mathrm{Xyl}}(6)$ & 12.500 & $\gamma_{\mathrm{BX}, \mathrm{Xyl}}(6)$ & 862.3 \\
\hline
\end{tabular}

Table A.5. Half-life of enzymes

\begin{tabular}{|c|c|c|}
\hline Parameter & Value (hour) & Ref. \\
\hline $\mathrm{t}_{\mathrm{EG} 1,1 / 2}$ & 42.5 & \multirow[t]{3}{*}{ Levine et al., 2010} \\
\hline $\mathrm{t}_{\mathrm{CBH} 2,1 / 2}$ & 42.5 & \\
\hline $\mathrm{t}_{\mathrm{CBH} 1,1 / 2}$ & 42.5 & \\
\hline $\mathrm{t}_{\mathrm{EX}, 1 / 2}$ & 12.5 & Hakulinen et al., 2003 \\
\hline$t_{B G, 1 / 2}$ & 12.5 & Assumed \\
\hline$t_{B X, 1 / 2}$ & 12.5 & Assumed \\
\hline
\end{tabular}


Table A.6. Inhibition parameters

\begin{tabular}{|c|c|c|c|c|c|}
\hline Parameter & $\begin{array}{c}\text { Value } \\
(1 / \mathrm{mM})\end{array}$ & Ref. & Parameter & $\begin{array}{c}\text { Value } \\
(1 / \mathrm{mM})\end{array}$ & Ref. \\
\hline$I_{E G 1, G l u}(1)$ & 0.06 & \multirow{24}{*}{$\begin{array}{l}\text { Zhang et } \\
\text { al., } 2014\end{array}$} & $I_{C B H 1, G l u}(1) I_{C B H 2, G l u}(1)$ & 0.032 & \multirow{12}{*}{$\begin{array}{l}\text { Zhang et } \\
\text { al., } 2014\end{array}$} \\
\hline$I_{E G 1, G l u}(2)$ & 0.13 & & $I_{C B H 1, G l u}(2) I_{C B H 2, G l u}(2)$ & 0.13 & \\
\hline$I_{E G 1, G l u}(3)$ & 0.3 & & $I_{C B H 1, G l u}(3) I_{C B H 2, G l u}(3)$ & 0.3 & \\
\hline$I_{E G 1, G l u}(4)$ & 0.37 & & $I_{C B H 1, G l u}(4) I_{C B H 2, G l u}(4)$ & 0.37 & \\
\hline$I_{E G 1, G l u}(5)$ & 0.44 & & $I_{C B H 1, G l u}(5) I_{C B H 2, G l u}(5)$ & 0.44 & \\
\hline$I_{E G 1, G l u}(6)$ & 0.51 & & $I_{C B H 1, G l u}(6) I_{C B H 2, G l u}(6)$ & 0.51 & \\
\hline$I_{E G 1, X y l}(1)$ & 0.06 & & $I_{C B H 1, X y l}(1) I_{C B H 2, X y l}(1)$ & 0.06 & \\
\hline$I_{E G 1, X y l}(2)$ & 2 & & $I_{C B H 1, X y l}(2) I_{C B H 2, X y l}(2)$ & 2 & \\
\hline$I_{E G 1, X y l}(3)$ & 2 & & $I_{C B H 1, X y l}(3) I_{C B H 2, X y l}(3)$ & 2 & \\
\hline$I_{E G 1, X y l}(4)$ & 4 & & $I_{C B H 1, X y l}(4) I_{C B H 2, X y l}(4)$ & 4 & \\
\hline$I_{E G 1, X y l}(5)$ & 10 & & $I_{C B H 1, X y l}(5) I_{C B H 2, X y l}(5)$ & 10 & \\
\hline$I_{E G 1, X y l}(6)$ & 11 & & $I_{C B H 1, X y l}(6) I_{C B H 2, X y l}(6)$ & 11 & \\
\hline$I_{E X, G l u}(1)$ & 0.06 & & & & \\
\hline$I_{E X, G l u}(2)$ & 0.13 & & & & \\
\hline$I_{E X, G l u}(3)$ & 0.3 & & & & \\
\hline$I_{E X, G l u}(4)$ & 0.37 & & & & \\
\hline$I_{E X, G l u}(5)$ & 0.44 & & & & \\
\hline$I_{E X, G l u}(6)$ & 0.51 & & & & \\
\hline$I_{E X, X y l}(1)$ & 0.4 & & & & \\
\hline$I_{E X, X y l}(2)$ & 0.85 & & & & \\
\hline$I_{E X, X y l}(3)$ & 1.5 & & & & \\
\hline$I_{E X, X y l}(4)$ & 2 & & & & \\
\hline$I_{E X, X y l}(5)$ & 4 & & & & \\
\hline$I_{E X, X y l}(6)$ & 4.5 & & & & \\
\hline
\end{tabular}

